\title{
Constraints on instantaneous ozone production rates and regimes during DOMINO derived using in-situ $\mathrm{OH}$ reactivity measurements
}

\author{
V. Sinha ${ }^{1,2}$, J. Williams ${ }^{1}$, J. M. Diesch ${ }^{3}$, F. Drewnick ${ }^{3}$, M. Martinez ${ }^{1}$, H. Harder ${ }^{1}$, E. Regelin ${ }^{1}$, D. Kubistin ${ }^{1}$, \\ H. Bozem ${ }^{1,6}$, Z. Hosaynali-Beygi ${ }^{1}$, H. Fischer ${ }^{1}$, M. D. Andrés-Hernández ${ }^{4}$, D. Kartal ${ }^{4}$, J. A. Adame ${ }^{5}$, and J. Lelieveld ${ }^{1}$ \\ ${ }^{1}$ Air Chemistry Division, Max-Planck-Institute for Chemistry, Mainz, Germany \\ ${ }_{2}^{2}$ Indian Institute of Science Education and Research Mohali, Sector 81, S. A. S. Nagar, Manauli PO, Punjab 140306, India \\ ${ }^{3}$ Particle Chemistry Department, Max-Planck-Institute for Chemistry, Mainz, Germany \\ ${ }^{4}$ Institute of Environmental Physics, University of Bremen, Bremen, Germany \\ ${ }^{5}$ Atmospheric Research and Instrumentation Branch, National Institute for Aerospace Technology (INTA), Mazagón-Huelva, \\ Spain \\ ${ }^{6}$ Institute for Atmospheric Physics, University of Mainz, Mainz, Germany
}

Correspondence to: V. Sinha (vsinha@iisermohali.ac.in)

Received: 13 January 2012 - Published in Atmos. Chem. Phys. Discuss.: 13 February 2012

Revised: 4 July 2012 - Accepted: 31 July 2012 - Published: 9 August 2012

\begin{abstract}
In this study air masses are characterized in terms of their total $\mathrm{OH}$ reactivity which is a robust measure of the "reactive air pollutant loading". The measurements were performed during the DOMINO campaign (Diel Oxidant Mechanisms In relation to Nitrogen Oxides) held from 21/11/2008 to 08/12/2008 at the Atmospheric Sounding Station - El Arenosillo $\left(37.1^{\circ} \mathrm{N}-6.7^{\circ} \mathrm{W}, 40 \mathrm{~m}\right.$ a.s.1.). The site was frequently impacted by marine air masses (arriving at the site from the southerly sector) and air masses from the cities of Huelva (located NW of the site), Seville and Madrid (located $\mathrm{NNE}$ of the site). $\mathrm{OH}$ reactivity values showed strong wind sector dependence. North eastern "continental" air masses were characterized by the highest $\mathrm{OH}$ reactivities (average: $31.4 \pm 4.5 \mathrm{~s}^{-1}$; range of average diel values: $21.3-40.5 \mathrm{~s}^{-1}$ ), followed by north western "industrial" air masses (average: $13.8 \pm 4.4 \mathrm{~s}^{-1}$; range of average diel values: $7-23.4 \mathrm{~s}^{-1}$ ) and marine air masses (average: $6.3 \pm 6.6 \mathrm{~s}^{-1}$; range of average diel values: below detection limit $-21.7 \mathrm{~s}^{-1}$ ), respectively. The average $\mathrm{OH}$ reactivity for the entire campaign period was $\sim 18 \mathrm{~s}^{-1}$ and no pronounced variation was discernible in the diel profiles with the exception of relatively high values from 09:00 to 11:00 UTC on occasions when air masses arrived from the north western and southern wind sectors. The measured $\mathrm{OH}$ reactivity was used to constrain both diel instantaneous ozone production potential rates and regimes. Gross ozone production rates at the site were generally lim-
\end{abstract}

ited by the availability of $\mathrm{NO}_{\mathrm{x}}$ with peak values of around $20 \mathrm{ppbV} \mathrm{O}_{3} \mathrm{~h}^{-1}$. Using the $\mathrm{OH}$ reactivity based approach, derived ozone production rates indicate that if $\mathrm{NO}_{\mathrm{x}}$ would no longer be the limiting factor in air masses arriving from the continental north eastern sector, peak ozone production rates could double. We suggest that the new combined approach of in-situ fast measurements of $\mathrm{OH}$ reactivity, nitrogen oxides and peroxy radicals for constraining instantaneous ozone production rates, could significantly improve analyses of upwind point sources and their impact on regional ozone levels.

\section{Introduction}

The hydroxyl radical $(\mathrm{OH} \cdot)$ plays a central role in the chemistry of the troposphere by controlling primary oxidation processes of volatile organic compounds (VOCs), daytime photochemical ozone production and formation of secondary organic aerosol. The hydroxyl radical reactivity (also termed total $\mathrm{OH}$ reactivity) of an air mass is defined in terms of the total loss rate of $\mathrm{OH}$ radicals due to the presence of $\mathrm{OH}$ reactants in the air mass and is expressed as:

$$
\text { Total OH reactivity }\left(\mathrm{s}^{-1}\right)=\sum k_{(X i+\mathrm{OH})}\left[X_{i}\right]
$$


where $k_{(\mathrm{Xi}+\mathrm{OH})}$ is the pseudo first order rate coefficient for the reaction of species $\mathrm{X}_{i}$ with $\mathrm{OH}$, and $\mathrm{X}_{i}$ stands for individual $\mathrm{OH}$ reactants present in an air mass such as carbon monoxide $(\mathrm{CO})$, sulphur dioxide $\left(\mathrm{SO}_{2}\right)$, nitrogen oxides $\left(\mathrm{NO}, \mathrm{NO}_{2}\right.$ ), and VOCs. Direct $\mathrm{OH}$ reactivity measurements are an invaluable tool as they provide a robust measure of the reactive pollutant "loading" of an air mass, considering that most air pollutants react primarily with the $\mathrm{OH}$ radical (Lelieveld et al., 2004). In addition, by combining direct $\mathrm{OH}$ reactivity measurements with simultaneous measurements of known $\mathrm{OH}$ sinks (e.g. $\mathrm{CO}, \mathrm{NO}_{\mathrm{x}}$ and $\mathrm{VOCs}$ ), it is possible to assess uncertainties in emissions and modeling of VOC budgets (e.g. Di Carlo et al., 2004). Despite such obvious importance, only few studies have reported direct $\mathrm{OH}$ reactivity measurements till date (e.g. Di Carlo et al., 2004; Hofzumahaus et al., 2010; Ingham et al., 2009; Kovacs et al., 2003; Ren et al., 2003; Sadanaga et al., 2004a; Sinha et al., 2010; Yoshino et al., 2006). One reason for this is that there are no commercial $\mathrm{OH}$ reactivity measurement instruments, and research instruments that are capable of making such measurements are based on sophisticated and expensive detectors such as laser induced fluorescence and proton transfer reaction mass spectrometers (Kovacs and Brune, 2001;Sadanaga et al., 2004b;Sinha et al., 2008). Amongst the available direct $\mathrm{OH}$ reactivity measurement dataset in the literature, the sites that have been studied encompass urban, suburban and forested sites in the United States (e.g. Di Carlo et al., 2004; Martinez et al., 2003; Ren et al., 2006), Japan (e.g. Sadanaga et al., 2004a; Yoshino et al., 2006), China (e.g. Hofzumahaus et al., 2010), United Kingdom (e.g. Ingham, 2009), Germany, Suriname and Finland (e.g. Sinha et al., 2008, 2010) and Malaysia (Ingham et al., 2009). Only one study has reported direct $\mathrm{OH}$ reactivity measurements from a coastal site, at the Weybourne Atmospheric Observatory on the North Norfolk coast, in the UK (Lee et al., 2009). Coastal sites provide the unique opportunity to contrast the chemistry of very different air masses such as marine influenced conditions, continental air or even urban and industrial air masses at a single location depending on the surrounding sources and the prevalent meteorology.

The DOMINO campaign (Diel Oxidant Mechanisms In relation to Nitrogen Oxides) was held from 21/11/2008 to 08/12/2008 at the Atmospheric Sounding Station - El Arenosillo, located on the Atlantic coast of southern Spain. Previous atmospheric chemistry studies at the site and in surrounding regions include investigations on the variability of surface ozone under a mesoscale circulation and in the cities of Huelva and Seville (Adame et al., 2008; Adame et al., 2010a; Adame et al., 2010b). Alastuey et al. (2006) performed chemical characterization of particulate matter sources in south west Spain while more recently, Diesch et al. (2012) studied the variability of aerosol, gaseous pollutants and meteorological characteristics associated with changes in air mass origin during the DOMINO campaign and found significantly higher fraction of aged organics in submicron aerosol particles sampled in air masses from the continental sector, when compared with air masses from other wind sectors. Direct $\mathrm{OH}$ reactivity measurements were made during DOMINO using the comparative reactivity method described by Sinha et al. (2008). These are the first $\mathrm{OH}$ reactivity measurements reported from Spain and enhance the direct $\mathrm{OH}$ reactivity measurement datasets in the literature to include south western Europe.

While several previous field studies (Di Carlo et al., 2004; Hofzumahaus et al., 2010; Ingham et al., 2009; Kovacs et al., 2003; Ren et al., 2003; Sadanaga et al., 2004a; Sinha et al., 2010; Yoshino et al., 2006) have focussed on testing the completeness of the suite of measured $\mathrm{OH}$ reactants by comparing the directly measured $\mathrm{OH}$ reactivity with the summed up calculated $\mathrm{OH}$ reactivity due the measured reactants by applying Eq. (1), in this study, we did not undertake this since the suite of VOCs measured during the campaign was not comprehensive enough to justify such an exercise.

Here, we focus on how the influence of air mass origin and history impacts the $\mathrm{OH}$ reactivity and ozone photochemistry at the coastal site El Arenosillo, which is downwind of several large cities in Spain such as Huelva, Seville and Madrid for substantial periods in the year. Employing insitu measurements of $\mathrm{OH}$ Reactivity, organic peroxy radicals $\left(\mathrm{RO}_{2}^{*}\right)$, hydroxyl and hydroperoxy radicals $\left(\mathrm{OH}, \mathrm{HO}_{2}\right)$ and $\mathrm{NO}_{\mathrm{x}}\left(\mathrm{NO}, \mathrm{NO}_{2}\right)$, we examine the diurnal instantaneous ozone formation regimes and rates of production potential in different air masses arriving at the site by a variety of approaches with implications for the future air quality of the region.

\section{Experimental}

\subsection{Site description and wind sector classification}

Figure 1a shows the location of El Arenosillo, $\left(37.1^{\circ} \mathrm{N}-\right.$ $6.7^{\circ} \mathrm{W}, 40 \mathrm{~m}$ a.s.l.) in southwestern Spain. Stone pine trees (Pinus pinea $\sim 5-10 \mathrm{~m}$ in height) were present in the immediate vicinity while the Atlantic Ocean was only $300 \mathrm{~m}$ south of the measurement site. The urban and industrial areas of Huelva city and the harbour (also shown in Fig. 1a) were located about $35 \mathrm{~km}$ north west of the measurement site. Huelva houses one of Europe's larger oil refineries and air masses from this sector contain emissions from related industrial / shipping activity. Madrid (also shown in Fig. 1a) was located about $600 \mathrm{~km}$ north-north east $(\sim 30$ degrees) of the measurement site while the city of Seville was closer and only about $70 \mathrm{~km}$ east-north east of the measurement site ( $\sim 60$ degrees). The wind rose of the measured $\mathrm{OH}$ reactivity is shown in Fig. 1b (right panel). Note that the $\mathrm{OH}$ reactivity was highly dependent on the wind sector from which air masses arrived at the site. The highest $\mathrm{OH}$ reactivity was observed in air masses arriving from the north eastern sector, followed by the north western sector and the southern sector. 


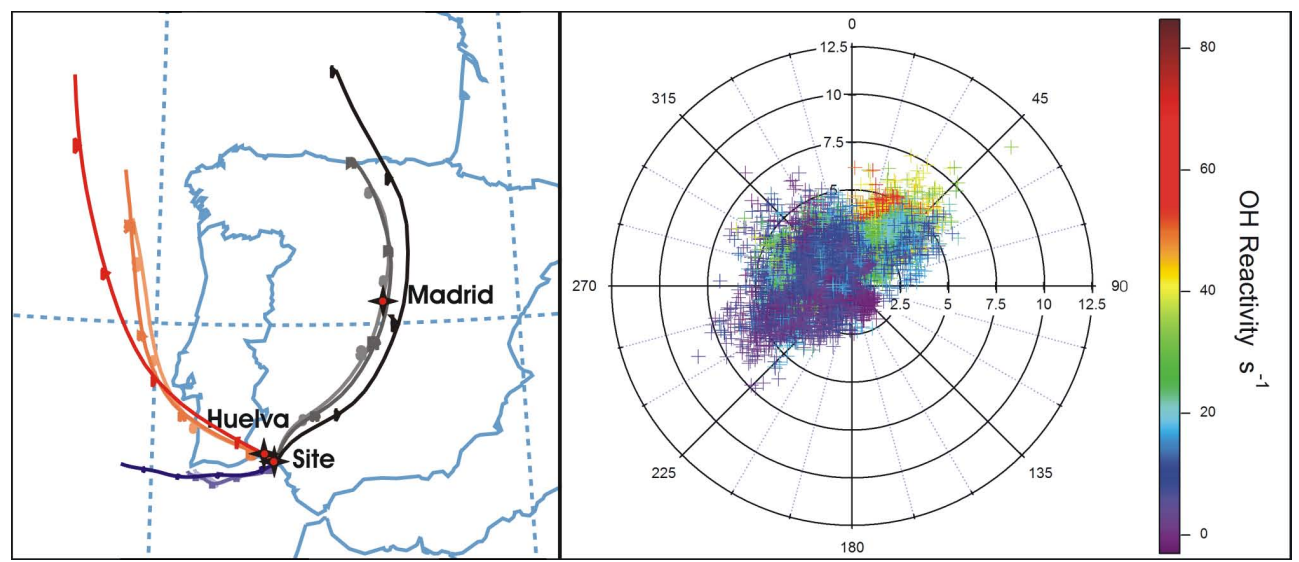

Fig. 1. (a) and (b) Location of the measurement site Base de Arenosillo, $37^{\circ} 05^{\prime} 58^{\prime \prime} \mathrm{N}, 6^{\circ} 44^{\prime} 17^{\prime \prime} \mathrm{W}$ ) as well as Madrid and Huelva (shown with starts) in Spain with select back trajectories at multiple heights from each wind sector (left panel) and wind rose plot showing OH Reactivity measurements (coloured markers and scale), wind speed (radii) and wind direction (angle) for the measurements made during the campaign (right panel).

In order to examine the impact of these "chemically" different air masses in a meaningful way, measurements of $\mathrm{OH}$ reactivity, nitrogen dioxide $\left(\mathrm{NO}_{2}\right)$, nitric oxide $(\mathrm{NO}), \mathrm{SO}_{2}$, ozone $\left(\mathrm{O}_{3}\right)$, formaldehyde ( $\left.\mathrm{HCHO}\right), \mathrm{OH}$ radical, $\mathrm{HO}_{2}$ radical and the $\mathrm{RO}_{2}^{*}$ were binned using three prevalent wind sectors and the rationale for the wind sector classification is presented shortly. It is worth noting that while short lived species such as $\mathrm{OH}$ radicals are not transported far from their point of production, their in-situ formation and destruction rates in an air mass does depend on the chemical composition and hence "history" of the air masses.

Based on dominant types of emission influencing the air masses, three different prevalent wind sectors were identified for this purpose, namely (1) the continental sector which was influenced mainly by aged air masses of continental origin (local wind direction: 0-60 degrees) (2) the Huelva sector (local wind direction: 270-340 degrees) which was heavily influenced by industrial and shipping emissions (3) the ocean sector (local wind direction: 150-270 degrees) which was characterized by relatively clean marine air except for occasional ship traffic. During the campaign period, the site received air masses from each of these different source sectors at least $25 \%$ of the time. Thus, the comparison of the measurements in air masses from these different wind sectors is statistically reasonable.

The classification of air masses in terms of local wind direction was also checked for consistency with back trajectories by combining information about the air mass back trajectories calculated using the NOAA HYSPLIT model with GDAS meteorology (Draxler and Rolph, 2011). For the Huelva sector and ocean sector the local wind direction was consistent with the calculated air mass back trajectories, for the continental sector, this was not always the case, the wind direction sometimes deviating by some 20 degrees from the direction of the corresponding 24-h back trajectory. This fact was taken into consideration while choosing the 0-60 degree sector wind direction for the continental air mass influence, which could otherwise have been a narrower sector if only wind direction or only back trajectories had been used.

This is illustrated further in Fig. 1a which shows selected back trajectories for each sector. Black and its lighter shades are for the continental sector, red and its lighter shades are for the Huelva sector; dark blue and its lighter shades are for the ocean sector, and the different shades merely indicate trajectories calculated at multiple heights $(20 \mathrm{~m}, 100 \mathrm{~m}$ and $500 \mathrm{~m}$ above ground level; darker the shade, higher the altitude). It should be noted from Fig. 1a that the back trajectories show similar characteristics for air masses arriving at different heights at the site which indicates the homogeneity of the first few hundred meters. The back trajectories also showed that the air masses arriving at the site stayed within the convective boundary layer during transport.

The trajectory shown for the continental sector in Fig 1a (black) corresponds to the highest measured $\mathrm{OH}$ reactivity values for the entire campaign period of $63-83 \mathrm{~s}^{-1}$ (see Fig. 1b), observed between 12:00 UTC and 14:00 UTC on $22 / 11 / 2008$. Interestingly this was also associated with the highest wind speeds of the campaign $\left(>5 \mathrm{~ms}^{-1}\right)$, which would have favoured long distance transport. As indicated by the trajectory which arrived at the measurement site at 12:00 UTC on 22/11/2008, the air masses had passed over Madrid less than $13 \mathrm{~h}$ previously. There is a mountain range about $1 \mathrm{~km}$ high just south of Madrid. Thus, instead of direct advection to El Arenosillo, emissions from Madrid and surrounding areas may undergo upward and horizontal transport accompanied by photochemical processing during the daytime boundary layer growth, and mix in with emissions from Seville and other upwind areas before arriving at El Arenosillo. The red coloured trajectories (Fig. 1a) depict the air masses that arrived from the Huelva sector at 21:00 UTC 
on 30/11/2008 and was associated with the highest $\mathrm{OH}$ reactivity values measured in air masses from this sector of $\sim 25$ $33 \mathrm{~s}^{-1}$, from 21:00-23:00 UTC on 30/11/2008, again at high wind speeds $\left(>4 \mathrm{~ms}^{-1}\right)$. Finally the blue coloured trajectories show the air masses that arrived at the site at 02:00 UTC on $07 / 12 / 2008$. Air masses from this sector generally brought very clean air and were characterized by low $\mathrm{OH}$ reactivity except for the odd $\mathrm{NO}_{\mathrm{x}}$ and $\mathrm{SO}_{2}$ peak. Consequently in air sampled from this sector, $\mathrm{OH}$ reactivity values were often below the instrumental detection limit of $3.5 \mathrm{~s}^{-1}$. For the blue trajectory shown in Fig. 1a, measured $\mathrm{OH}$ reactivity values were always less than the detection limit.

\subsection{OH reactivity measurements}

$\mathrm{OH}$ reactivity was measured using the comparative reactivity method. The method has been described in detail in previous publications (Sinha et al., 2008, 2010) hence only a brief description and details pertinent to the operational parameters during the DOMINO campaign are described here.

The comparative reactivity method for $\mathrm{OH}$ reactivity measurement employs an in situ competitive kinetics experiment in which a proton transfer reaction mass spectrometer (PTRMS) is coupled to a turbulent flow glass reactor. Pyrrole $\left(\mathrm{C}_{4} \mathrm{H}_{5} \mathrm{~N}\right)$ is introduced into the reactor and its concentration $\mathrm{C} 1$ is monitored with a PTR-MS, in the air exiting the reactor. Then, synthetically generated $\mathrm{OH}$ radicals $([\mathrm{OH}]<$ [Pyrrole]) are introduced into the reactor at a constant rate to react with pyrrole. This causes $\mathrm{C} 1$ to decrease to concentration $\mathrm{C} 2$. When ambient air is introduced into the reactor, the various species present in it compete with pyrrole for the available $\mathrm{OH}$, so that the concentration of pyrrole increases to $\mathrm{C} 3$. Comparing the amount of pyrrole exiting the reactor in the zero air (C2) and ambient air (C3), allows the introduced air sample's $\mathrm{OH}$ reactivity to be determined, provided the system is suitably calibrated for pyrrole (Sinha et al., 2009). The following equation, a derivation of which is available elsewhere (Sinha et al., 2008), yields the measured $\mathrm{OH}$ reactivity signal in terms of $\mathrm{C} 1, \mathrm{C} 2, \mathrm{C} 3$ and the rate coefficient of pyrrole with the $\mathrm{OH}$ radical $\left(k_{\mathrm{p}}=1.2 \times 10^{-10}\right.$ molecules $\mathrm{cm}^{-3} \mathrm{~s}^{-1}$ (Atkinson et al., 1984):

$R_{\text {air }}=\frac{(\mathrm{C} 3-\mathrm{C} 2)}{(\mathrm{C} 1-\mathrm{C} 3)} \cdot k_{\mathrm{p}} \mathrm{C} 1$

The values obtained using Eq. (2) are corrected for deviations from pseudo first order conditions using the pyrrole to $\mathrm{OH}$ ratio (i.e. $\mathrm{C} 1 /(\mathrm{C} 1-\mathrm{C} 2)$ ), and for the dilution of ambient air within the reactor. For the DOMINO campaign the pyrrole / $\mathrm{OH}$ ratio was $\sim 1.7$ leading to a correction factor that lowers the values obtained from Eq. (2) by $\sim 30 \%$. Frequent tests (at least every other day) with air samples of known $\mathrm{OH}$ reactivity, were performed and excellent accountability for $\mathrm{OH}$ reactivity of the test samples was obtained. A propane gas standard (Westfalen A.G.; $33 \mu \mathrm{mol} \mathrm{mol}{ }^{-1}$; stated uncertainty $4 \%$ ) was used to introduce test samples of different
$\mathrm{OH}$ reactivities through the same reactor arm that is used to introduce ambient air into the glass reactor.

The range of $\mathrm{OH}$ reactivities investigated using the propane test samples during DOMINO was $6.9 \mathrm{~s}^{-1}-32.1 \mathrm{~s}^{-1}$. The slope of the measured reactivity versus theoretical reactivity for all the tests $(n=9)$ was $0.88 \pm 0.07$ with an offset of $0.01 \pm 1.18$. The precision error (index of reproducibility) determined using twice the standard deviation (2 sigma) of the slopes obtained on $22 / 08 / 2008$ and $09 / 11 / 2008$ was $3.2 \%$.

The humidity of the air in the reactor is tracked for every data point that is measured, using the $\mathrm{m} / \mathrm{z}=55$ signal corresponding to the $\left(\mathrm{H}_{2} \mathrm{O}\right)_{2} \mathrm{H}_{3} \mathrm{O}^{+}$ion in the PTR-MS (e.g. Sinha et al., 2008 and Amman et al., 2006). Thus for every zero air measurement (corresponding to $\mathrm{C} 2$ signal of pyrrole) and ambient air measurement (corresponding to $\mathrm{C} 3$ signal of pyrrole) in the reactor, the values of $m / z=55$ are known. If the humidity of the introduced ambient air/zero air is the same, the $m / z=55$ signal while measuring $\mathrm{C} 2$ and $\mathrm{C} 3$ is also the same. On the other hand if the humidity of the introduced zero air and ambient air are different, the $\mathrm{m} / z=55$ signal will also be different. During DOMINO we found that the maximum observed difference in the $\mathrm{m} / z=55$ signal between ambient and zero air due to humidity differences, would cause an uncertainty of $\sim 5 \%$ in the measured $\mathrm{OH}$ reactivity. This in turn was determined by measuring the change in the pyrrole signal as a result of just changing the humidity of the zero air (a direct measure of the changing $\mathrm{OH}$ concentration due to the changing humidity). This effect has already been described in detail in Sinha et al. (2008). The humidification of the zero air flow was adjusted (using a commercial humidifier from Bronkhorst, Germany) to match the ambient air flow, by using the $\mathrm{m} / \mathrm{z}=55$ signal as the humidity proxy. These measurement settings are similar to that employed previously for measurements within a boreal forest in Finland (Sinha et al., 2010). Only three differences are worth mentioning. The inlet residence time during the DOMINO campaign was $<4 \mathrm{~s}$, compared to the inlet residence time of $<8 \mathrm{~s}$ during the previous study in Finland. The reactor residence time was $\sim 20 \mathrm{~s}$, resulting in a total sampling time of $24 \mathrm{~s}$. The second difference was that the main sampling inlets were heated to a temperature of 40 degree Celsius for the entire campaign period during DOMINO. Thirdly, fast measurements of $\mathrm{OH}$ reactivity were performed by switching rapidly between baseline (corresponding to $\mathrm{C} 2$ of measured pyrrole signal) and the ambient air (corresponding to $\mathrm{C} 3$ of measured pyrrole signal) every $4 \mathrm{~min}$.

Ambient air was sampled into the glass reactor at $180 \mathrm{ml} \mathrm{min}^{-1}$ in a total flow of $300 \mathrm{ml} \mathrm{min}^{-1}$ leading to a dilution factor of 1.7. A Teflon VOC pump was used to draw a fraction of the fast flow from the $\sim 15 \mathrm{~m}$ long main inlet Teflon tubing ( $12.7 \mathrm{~mm}$ outer diameter) which was at a height of $12 \mathrm{~m}$ above ground, and fitted with a Teflon filter to prevent particles from clogging the lines. 
The detection limit for the $\mathrm{OH}$ reactivity measurements during this study was $3.5 \mathrm{~s}^{-1}$. The overall uncertainty of the measured $\mathrm{OH}$ reactivity was $\sim 20 \%$, obtained by applying the root square propagation of uncertainties due to (1) rate coefficient of pyrrole $+\mathrm{OH}(14 \%)$, (2) overall flow fluctuation $(10 \%)$, (3) uncertainty in value of the pyrrole standard (5\%), (4) precision error of PTR-MS (4\%), and (5) error in matching the humidity of the ambient air exactly $(5 \%)$. Note however that close to the detection limit the overall uncertainty can be larger than $20 \%$ as noted in Sinha et al. (2008). NO mixing ratios exceeding $10 \mathrm{ppbV}$ in ambient air are known to cause underestimation of the measured $\mathrm{OH}$ reactivity in the comparative reactivity method (Sinha et al., 2008). However, the NO levels in the ambient air during DOMINO were too low to cause any interference. Values of $\mathrm{NO}$ during the campaign ranged from below $0.01 \mathrm{ppbV}$ to a maximum of $8.2 \mathrm{ppbV}$ in a single event on $05 / 12 / 2008$ at 12:15 UTC. The average value of NO in ambient air for the entire campaign was only $0.21 \pm 0.6 \mathrm{ppbV}$, hence no corrections were required for the $\mathrm{OH}$ reactivity data on account of the NO interference during DOMINO.

\subsection{Simultaneous ancillary measurements}

All other measurements used in this study were collocated and performed from the same mast with less than $1 \mathrm{~m}$ separating the inlets of individual instruments. The only exception were $\mathrm{O}_{3}$ and $\mathrm{SO}_{2}$ which were measured from a neighboring inlet ( $<3 \mathrm{~m}$ away) installed on the mast of a mobile van at a height of $10 \mathrm{~m}$ above ground (Diesch et al., 2012). As details regarding the measurements of $\mathrm{NO}, \mathrm{NO}_{2}, \mathrm{HCHO}, \mathrm{OH}$ and $\mathrm{HO}_{2}$ radicals during the DOMINO campaign have already been described elsewhere (Crowley et al., 2011; Sörgel et al., 2011) only a short description is given below.

\subsection{1 $\mathrm{NO}_{\mathrm{x}}\left(\mathrm{NO}, \mathrm{NO}_{2}\right)$ measurements}

$\mathrm{NO}$ and $\mathrm{NO}_{2}$ measurements were made using a high resolution and high sensitivity chemiluminescence detector (ECOPhysics CLD 790 SR, originally manufactured by ECOPhysics, Durnten, Switzerland). NO is measured directly, however, $\mathrm{NO}_{2}$ is measured indirectly after conversion to $\mathrm{NO}$ using a blue light converter which is a solid state photolytic converter (Droplet Measurement Technologies, Boulder, CO, USA). The total uncertainty including the precision and accuracy error was $6.04 \mathrm{ppt}(+5 \%$ of the measured value for $\mathrm{NO})$ and $8.29 \mathrm{ppt}\left(+8 \%\right.$ of the measured value for $\mathrm{NO}_{2}$ ) for an integration period of $1 \mathrm{~s}$. A detailed description of the instrument and calibration techniques can be found in Hosaynali Beygi et al. (2011).

\subsection{2 $\mathrm{OH}$ and $\mathrm{HO}_{2}$ measurements}

$\mathrm{OH}$ and $\mathrm{HO}_{2}$ measurements were made using laser induced fluorescence spectroscopy. Details of the instrument are available elsewhere (Martinez et al., 2010). The accuracy of the $\mathrm{OH}$ and $\mathrm{HO}_{2}$ measurement was $\pm 18 \%$ and the precision was 0.034 pptv for $\mathrm{OH}$ and 0.23 pptv for $\mathrm{HO}_{2}$.

After the DOMINO campaign, laboratory tests established an interference for the $\mathrm{OH}$ measurement. To estimate the magnitude of the interference follow up measurements were performed in the same season in 2009. They indicated an $\mathrm{OH}$ interference of about $60 \%$ between 10 a.m. and 3 p.m. (UTC) (E. Regelin, personal communication, 2011). In a recent paper by Fuchs et al. (2011), an $\mathrm{HO}_{2}$ interference is discussed due to presence of $\mathrm{RO}_{2}$ radicals, in particular if the $\mathrm{RO}_{2}$ is originating from $\mathrm{OH}$ addition to alkenes or aromatics. The author reports for their instrument an interference of up to $95 \%$ depending on the type of $\mathrm{RO}_{2}$. In this study we cannot exclude this possible interference for the $\mathrm{HO}_{2}$ measurement presented.

Hence for the purpose of this study, the presented $\mathrm{OH}$ and $\mathrm{HO}_{2}$ measurements are considered as upper limits.

\subsubsection{Formaldehyde (HCHO) measurements:}

A commercially available instrument (AERO Laser model AL 4021, Germany) was used for in-situ HCHO measurements. This instrument is based on the Hantzsch reagent method. The time resolution is $160 \mathrm{~s}$. Detection limit and precision were estimated from the $1 \sigma$ reproducibility of insitu zero and calibration gas measurements as $22 \mathrm{pptv}$ and $\pm 15 \%$, respectively. The total uncertainty is estimated to be $29 \%$.

\subsubsection{Sum of $\mathrm{HO}_{2}$ and organic peroxy radicals}

$\mathrm{RO}_{2}^{*}$ which represents the sum of all peroxy radicals $\left(\mathrm{RO}_{2}^{*}=\mathrm{HO}_{2}+\Sigma \mathrm{RO}_{2}\right.$ where $\mathrm{R}$ stands for organic chain), was measured using a DUALER (DUAl channeL peroxy radical chemical amplifiER) adapted for ground based measurements. The instrument uses the well known PeRCA (Peroxy Radical Chemical Amplification) technique (Hastie et al., 1991; Cantrell et al., 1993). The technique converts ambient peroxy radicals into $\mathrm{NO}_{2}$, which is detected by measuring the chemiluminiscence of its reaction with luminol. There are two identical lines working in alternate modes, i.e., an amplification mode resulting from the chemical conversion of $\mathrm{RO}_{2}^{*}$ into $\mathrm{NO}_{2}$ in a chain reaction above the $\mathrm{NO}_{2}$ background levels, and a background mode comprising $\mathrm{NO}_{2}$ and all $\mathrm{NO}_{2}$ sources other than radicals in the air sampled and up to the detector such as reaction of $\mathrm{NO}$ with $\mathrm{O}_{3}$, the decomposition of PAN, etc. (Kartal et al., 2010). For the set up deployed within DOMINO the total uncertainty of 1 min averages was $30 \%$ for RH at $60 \%$ (detection limit $1-3$ pptv) and $60 \%$ for RH between 70-90\%, (5-10 pptv detection limit). For DOMINO the data were analysed considering the calibration of the PerCA instrument only for $\mathrm{HO}_{2}$. The detection limit refers to this $\mathrm{HO}_{2}$ calibration. For the radical measurements, this can lead to an underestimation of the total sum of radicals as other peroxy radicals might have less losses 


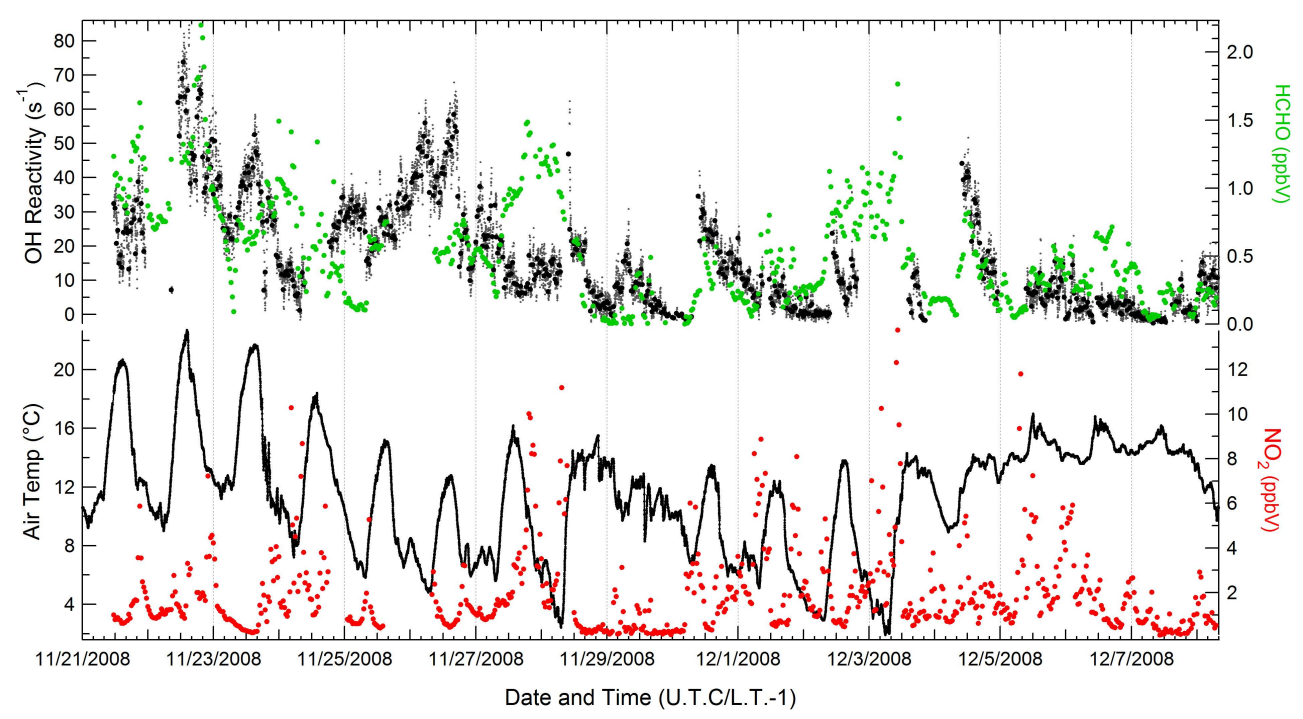

Fig. 2. Time series of the $1 \mathrm{~min}$ (gray dots; $n=11584$ measurements) and 30 minute averages (black circles) of the OH reactivity data during the DOMINO campaign (top panel) and the $30 \mathrm{~min}$ averages of the formaldehyde (HCHO) mixing ratios (green circles), the ambient temperature (solid black line) and nitrogen dioxide $\left(\mathrm{NO}_{2}\right)$ mixing ratios (red circles) (bottom panel).

before the amplification zone in the reactor. Laboratory experiments using different $\mathrm{HO}_{2}+\mathrm{RO}_{2}$ mixtures indicated that for $50 \%\left[\mathrm{HO}_{2}\right]$ in the air mass, $\left[\mathrm{RO}_{2}^{*}\right]$ is underestimated by $15 \%$ in the DUALER reactor used for DOMINO.

\subsubsection{Ozone $\left(\mathrm{O}_{3}\right)$, sulphur dioxide $\left(\mathrm{SO}_{2}\right)$ and meteorological measurements}

$\mathrm{O}_{3}$ and $\mathrm{SO}_{2}$ were measured using commercial instruments (Airpointer, Recordum GmbH, Austria). Meteorological parameters like temperature, relative humidity (RH), atmospheric pressure, wind speed and wind direction were measured with a Vaisala WXT510 15125 (Vaisala, Helsinki, Finland) meteorological station equipped at $10 \mathrm{~m}$ above ground level on the mobile laboratory (MoLa) (Diesch et al., 2012). Limits of detection and precision were $1 \mathrm{ppb}$ for both $\mathrm{SO}_{2}$ and $\mathrm{O}_{3}$.

\section{Results and discussion}

\subsection{General trends in $\mathrm{OH}$ Reactivity and dependency on air masses}

Figure 2 (top panel) shows the time series of the 1 minute (gray dots; $n=11584$ measurements) and 30 minute averages (black circles) of the $\mathrm{OH}$ reactivity data during the DOMINO campaign. The $\mathrm{OH}$ reactivity ranged from below detection limit $\left(\sim 3.5 \mathrm{~s}^{-1}\right)$ to $84 \mathrm{~s}^{-1}$, the latter being observed between 12:00 UTC and 14:00 UTC on 22/11/2008 when air mass that had passed over Madrid and Seville region less than 13 hours earlier arrived at the site from the Continental sector (local wind direction: 0-60 degrees; see also Fig. 1a and Sect. 2.1). Also shown in the top panel of Fig. 2 are the $30 \mathrm{~min}$ averages of the $\mathrm{HCHO}$ mixing ratios (green circles) and in the bottom panel, a time series of the ambient temperature (solid black line) and $\mathrm{NO}_{2}$ mixing ratios (red circles). Overall, there was considerable variability in the $\mathrm{OH}$ reactivity with an average of $18 \pm 15 \mathrm{~s}^{-1}$ for the entire campaign. The ambient temperature ranged from $2-$ $23^{\circ} \mathrm{C}$ with the first four days from $21 / 11 / 2008-24 / 11 / 2008$ generally warmer than the other periods of the campaign. As shown in Fig. 2, HCHO an oxidation product formed during the $\mathrm{OH}$ initiated oxidation of many VOCs (Atkinson, 2003), appeared to correlate with the profile of the measured $\mathrm{OH}$ reactivity for extended periods on certain days of the campaign such as: 21/11/2008-23/11/2008; 30/11/2008-01/12/2008; $04 / 12 / 2008-06 / 12 / 2008$ and 07/12/2008-08/12/2008. We note that during most of these periods of co-variations, $\mathrm{OH}$ reactivity and $\mathrm{HCHO}$ profiles have a plume like character, rising and falling concomitantly. The most frequent wind direction in all these periods is the continental wind sector and sometimes air masses close to the continental sector but falling in the Huelva urban area (see for e.g. Fig. 4 in Diesch et al., 2012). If HCHO be regarded as a proxy for oxidation products, it is expected to be present at higher levels in photochemically aged air masses. Moreover, the likelihood of other reactive oxidation products being present at elevated levels, just like $\mathrm{HCHO}$ in air masses arriving in plume like fashion, is a likely explanation for the observed co-variations of $\mathrm{HCHO}$ with the measured $\mathrm{OH}$ reactivity. The correlation coefficient between the $30 \mathrm{~min} \mathrm{OH}$ reactivity and $\mathrm{HCHO}$ data for the entire campaign is only $r=0.5$.

Some high values were observed between 24/11/2008 and 27/11/2008. After checking for the prevalent wind direction 
for this period we found that on 24/11/2008, continental air masses were sampled for a short while before the air masses started coming from the Huelva wind sector for much of 25.11 and 26.11. This was also the period when several spikes in $\mathrm{SO}_{2}$ and $\mathrm{NO}_{\mathrm{x}}$ were observed (e.g. see Fig. 4 of Diesch et al., 2012). High $\mathrm{NO}_{2}$ values acted as a marker for pollution plumes arriving at the site. This happened quite frequently as can be seen in Fig. 2, and although the average value for $\mathrm{NO}_{2}$ was low $(1.9 \pm 1.9 \mathrm{ppbV}$ for the entire campaign), occasionally peak values of $\sim 13 \mathrm{ppbV}$ were also observed during the campaign (see Fig. 2). As mentioned in Sect. 2.1, the measurement site was surrounded by a forest of Stone pine trees. However, Song et al. (2011) who measured biogenic VOCs such as monoterpenes and isoprene during DOMINO, found their levels to be low (average value of terpenes for the entire campaign period: $\sim 10 \mathrm{pptv}$ ) with the highest value of $140 \mathrm{pptv}$ for isoprene. This is consistent with previous seasonal studies of this vegetation (Keenan et al. 2009: Staudt et al. 2000). Aromatic VOCs such as benzene, toluene and xylene, which were also measured by Song et al. (2011) were marginally higher with mean values in the range of 10-156 pptV for the entire campaign. Methane was measured using a gas chromatograph equipped with a flame ionization detector (GC-FID). Instrumental details can be found in Sinha et al. (2007). The average methane value of $1.87 \mathrm{ppmV}$ for the entire campaign contributed only $0.3 \mathrm{~s}^{-1}$ of $\mathrm{OH}$ reactivity. Thus the contribution of methane, the measured biogenic VOCs and aromatic VOCs to the $\mathrm{OH}$ reactivity was extremely low $\left(<1.5 \mathrm{~s}^{-1}\right.$ on average). While $\mathrm{CO}$ measurements are unavailable at El Arenosillo due to instrumental failure, average $\mathrm{CO}$ levels at the nearby air quality station in Mazagon, Huelva $\left(37.1^{\circ} \mathrm{N}-6.8^{\circ} \mathrm{W}\right)$ for the same period as the DOMINO campaign were about $680 \mathrm{ppb} \mathrm{CO}$ (J. A. Adame, personal communication, 2012). The Mazagon station is heavily influenced by local traffic and industrial emissions and so the $\mathrm{CO}$ measurements cannot be considered representative for El Arenosillo. Nevertheless they do suggest the presence of large CO point sources in the Huelva sector. Unfortunately, other anthropogenic VOCs such as the C2-C8 alkanes and alkenes which are known to be present in continental, urban and industrial emissions (e.g. Monks et al., 2009) were not measured during DOMINO, so information about their levels is unavailable.

Figure 3a shows a diel box and whisker plot of the measured total $\mathrm{OH}$ reactivity at El Arenosillo, derived from all measurements $(n>11500)$. The range of $\mathrm{OH}$ reactivity even for the same hour of the day shows considerable day to day variability (Below Detection Limit to $48 \mathrm{~s}^{-1}$ ). We note that except at 10:00 and 11:00 UTC, every other time of the day has some values close to the detection limit of $3.5 \mathrm{~s}^{-1}$ in the 10th percentile (lower whisker). These values correspond to periods when clean air masses from the ocean sector were sampled at the site (see also Fig $1 \mathrm{~b}$ ). The average and median span a range of $9-25 \mathrm{~s}^{-1}$, with the average always greater than or equal to the median, consistent with frequent pol-
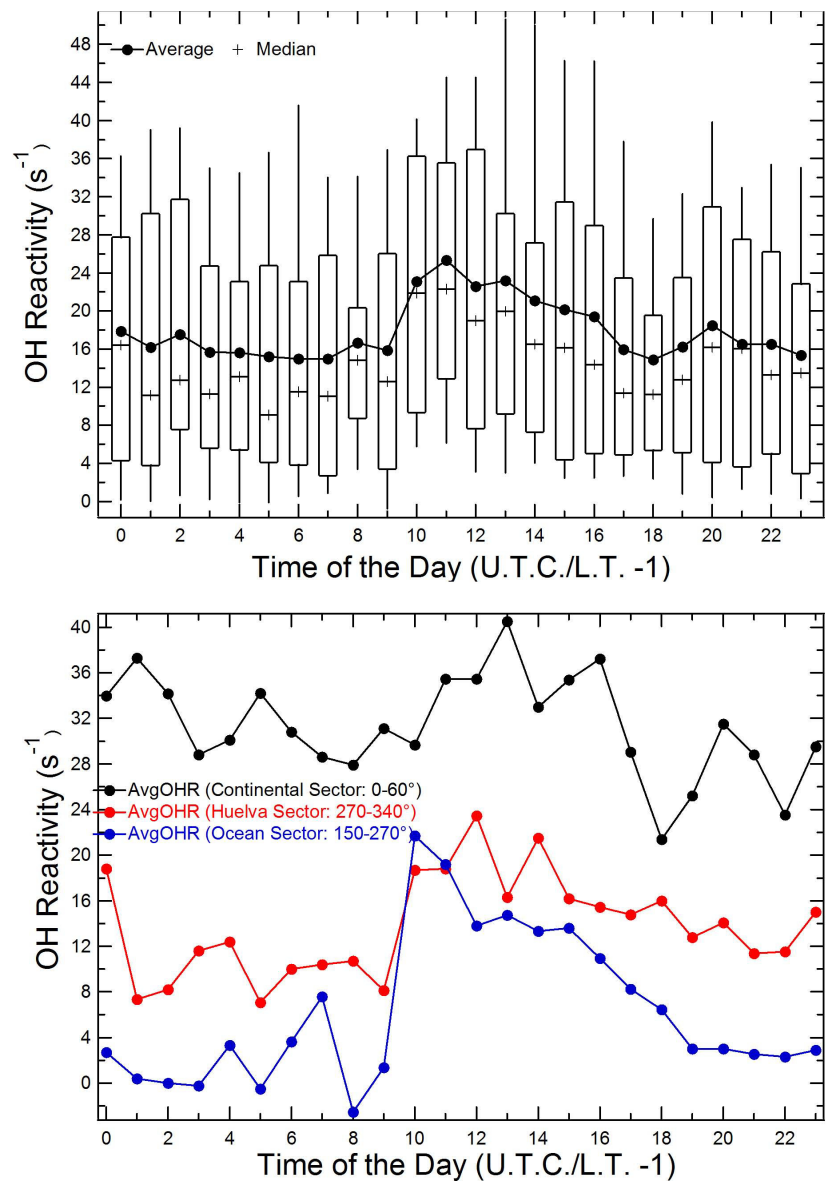

Fig. 3. (a) and (b) Diel box and whisker plot of the total $\mathrm{OH}$ reactivity at Base de Arenosillo $\left(37^{\circ} 05^{\prime} 58^{\prime \prime} \mathrm{N}, 6^{\circ} 44^{\prime} 17^{\prime \prime} \mathrm{W}\right)$ derived from all measurements $(n>11500)$ during the DOMINO campaign (top) and average diel profile of $\mathrm{OH}$ reactivity for air masses from the Continental (black), Huelva (red) and Ocean (blue) wind sectors.

lution plumes being sampled at the site as indicated by the $\mathrm{NO}_{2}$ time series shown in Fig. 2. Both median and average OH Reactivity values are generally higher between 09:0015:00 UTC but there does not seem to be a pronounced diel cycle. The strong peak between 09:00-11:00 UTC was probably due to both ship emissions from the ocean (150-270 degrees) and traffic emissions from the Huelva wind sectors (270-340 degrees). The average diel profile for each wind sector, which is discussed next, and the high average $\mathrm{NO}_{\mathrm{x}}$ and $\mathrm{SO}_{2}$ values between 09:00-11:00 UTC in air masses from these sectors which are shown in Figs. 4 and 5 appears to support this hypothesis. Figure $3 b$ shows the average diel profile of $\mathrm{OH}$ reactivity for air masses from each wind sector, namely the continental (black markers), Huelva (red markers) and ocean (blue markers) sectors. Clearly, the highest average $\mathrm{OH}$ reactivity was always in air masses that arrived from the continental sector carrying aged and processed emissions followed by the Huelva sector and the 


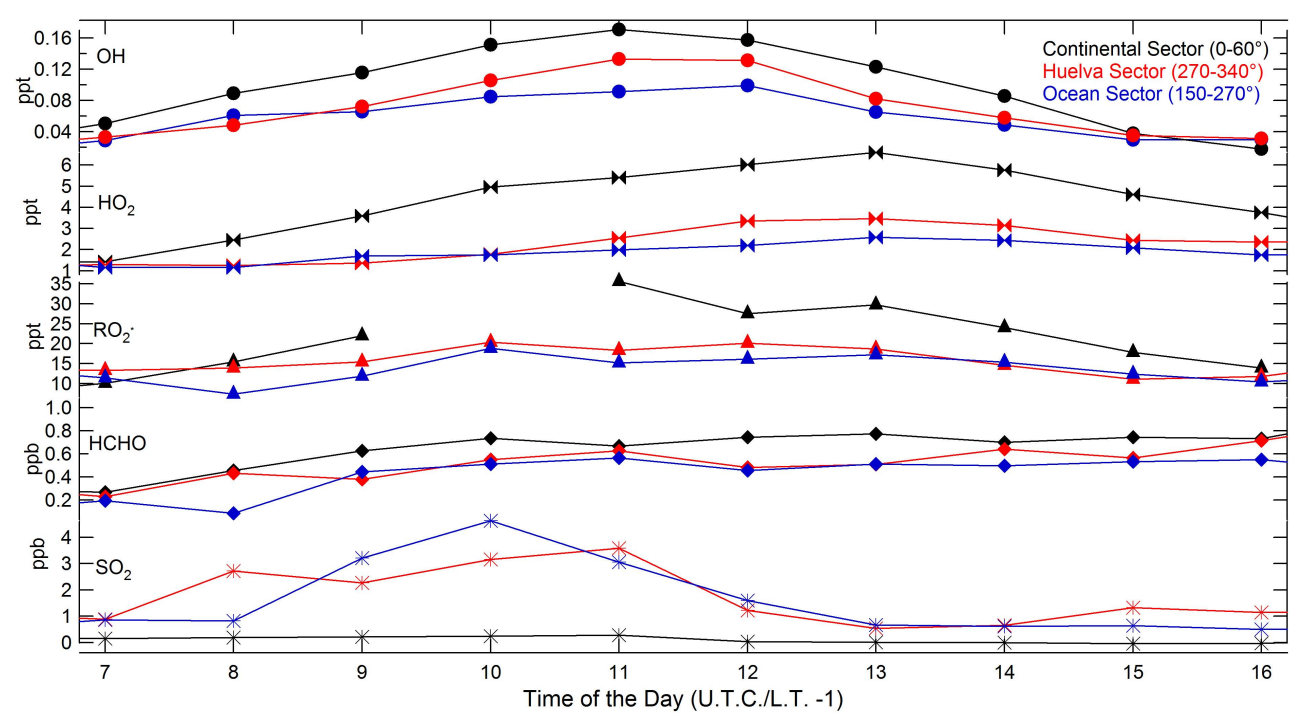

Fig. 4. Average diurnal profiles of the hydroxyl radical $(\mathrm{OH})$, hydroperoxy radical $\left(\mathrm{HO}_{2}\right)$, sum of peroxy radicals $\left(\mathrm{RO}_{2}^{*}\right)$, formaldehyde ( $\mathrm{HCHO})$ and sulphur dioxide $\left(\mathrm{SO}_{2}\right)$ in air masses from the continental, huelva and ocean wind sectors.

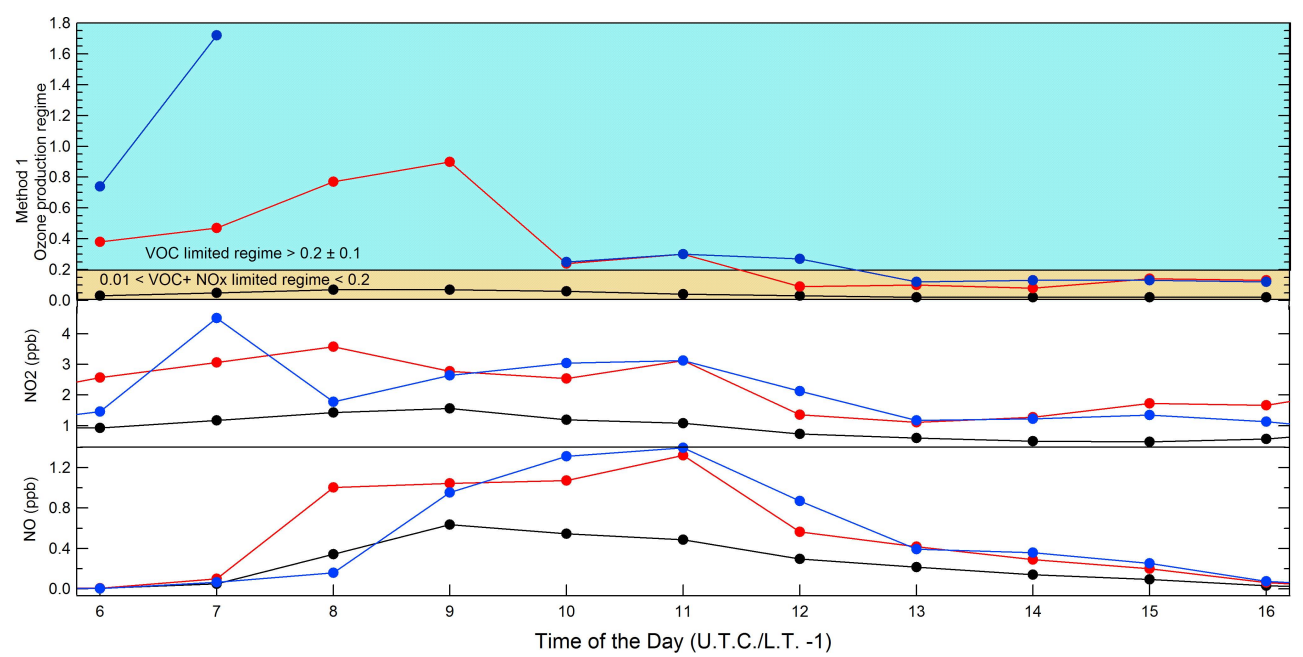

Fig. 5. Instantaneous diurnal ozone production regime for each of the three air mass sectors, namely, Continental (black markers), Huelva (red markers), and Ocean (blue markers) using Method 1 (top panel) and average diurnal $\mathrm{NO}_{\mathrm{x}}\left(\mathrm{NO}, \mathrm{NO}_{2}\right)$ mixing ratios (bottom panels).

ocean sector. The average and diel range of the $\mathrm{OH}$ reactivities for each of the sectors were: continental sector (average: $31.4 \pm 4.5 \mathrm{~s}^{-1}$; range: $21.3-40.5 \mathrm{~s}^{-1}$ ), Huelva sector (average: $13.8 \pm 4.4 \mathrm{~s}^{-1}$; range: $7-23.4 \mathrm{~s}^{-1}$ ), ocean sector (average: $6.3 \pm 6.6 \mathrm{~s}^{-1}$; range: below detection limit $-21.7 \mathrm{~s}^{-1}$ ). The highest average $\mathrm{OH}$ reactivity of $20 \mathrm{~s}^{-1}$ at 10:00 UTC. in the ocean sector air masses as discussed earlier is likely due to ship traffic and mixed in industrial emissions from the Huelva harbour area.

The average value of $6 \mathrm{~s}^{-1}$ for the ocean sector is comparable to the average value of $5 \mathrm{~s}^{-1}$ reported by Ingham et al. (2009) and Lee et al. (2009) from the Weybourne Atmospheric Observatory in UK, which is on the North Sea coast. They are also quite close to the average value of $4 \mathrm{~s}^{-1}$ re- ported by Mao et al. (2009) over the Pacific Ocean during the INTEX-B campaign between 0-2 km above sea level. Remarkably, the average value of $13.8 \mathrm{~s}^{-1}$ for the Huelva sector is quite similar to the median value of $11.3 \mathrm{~s}^{-1}$ reported by Kovacs et al. (2003) from a site $8 \mathrm{~km}$ downwind of Nashville $\mathrm{TN}$ in the United States. Both Huelva city and Nashville TN have large petrochemical industries. In addition, Huelva also houses Spain's largest pulp/paper mill. As the distance of these sources was less than $35 \mathrm{~km}$ from the measurement site during DOMINO, emissions from such anthropogenic sources are expected to have contributed significantly to the $\mathrm{OH}$ reactivity in air masses arriving from the Huelva sector.

The average $\mathrm{OH}$ reactivity of $\sim 31 \mathrm{~s}^{-1}$ measured in continental sector air masses is remarkably high for the fact that 
there were no obvious nearby strong point emission sources in this sector. The fact that highest values were observed at the highest wind speeds (see Fig. 1b) and sustained levels of high average $\mathrm{OH}$ reactivity $>20 \mathrm{~s}^{-1}$ by day and night were observed whenever the air came from the continental sector, also indicates that the species responsible for the high $\mathrm{OH}$ reactivity did not have local sources. Aged air masses can contain significant amounts of reactive oxidation products formed due to photochemical processing of the primary anthropogenic emissions such as alkanes and alkenes (Butler et al., 2011). As shown in Fig. 1a, the transport time of less than 13 hours for air masses that had passed over Madrid, implies that a significant fraction of the emissions from Madrid, and indeed more reactive secondary oxidation products from precursors such as alkanes and aromatic VOCs (Lee et al., 2009) would still be present in these air masses. We note that the urban centre of Madrid, its surrounding industrial areas and the industrial region of Seville are arguably amongst the largest point sources in Spain. In particular the Seville industrial area has high emissions from solvent use and associated products which alone amounted to $2050 \mathrm{Mg} \mathrm{yr}^{-1}$ of NMVOC emissions in 2007 (Source: EMEP, UNECE 2009). Several reactive anthropogenic alkenes (e.g. 1,3-butadiene, isobutene, trans-2 butene, pent2-ene, hexenes and heptenes), multi substituted mono aromatic compounds (e.g. 1,2,4-trimethyl benzene and 2,4,6-trimethyl benzene) and oxygenated VOCs (e.g. acetaldehyde, hydroxy acetone) and higher alkanes (e.g. methyl pentane, hexane, heptanes), were not measured during DOMINO. We speculate that the highest observed $\mathrm{OH}$ reactivities could be due to a mixture of these emissions and their oxidation products. Using sensitive 2-dimensional gas chromatography, Lewis et al. (2000) detected more than 500 chemical species of volatile organic compounds in urban air, including over 100 multi-substituted monoaromatic and volatile oxygenated hydrocarbons. Even if 300 out of 500 such compounds were present at $100 \mathrm{pptV}$ and had a rate coefficient comparable to isobutene or trimethyl benzene $\left(k_{\mathrm{X}+\mathrm{OH}}>5 \times 10^{-11} \mathrm{~cm}^{3}\right.$ molecule ${ }^{-1} \mathrm{~s}^{-1}$ or half as reactive as isoprene), the total would contribute about $38 \mathrm{~s}^{-1}$ of $\mathrm{OH}$ reactivity, explaining the extremely high values above the average background from this sector $\left(\sim 30 \mathrm{~s}^{-1}\right)$. The only alkane that was measured during DOMINO was methane and average methane levels followed the same trend as observed in the average $\mathrm{OH}$ reactivity levels namely: Continental wind sector (WS) $(1.88 \mathrm{ppmV})>$ Huelva WS $(1.86 \mathrm{ppmV})>$ Ocean WS $(1.85 \mathrm{ppmV})$. Most of the $\mathrm{NO}_{\mathrm{x}}$ would however have reacted away, and as shown later in Fig. 5, this was indeed the case. Such high levels of $\mathrm{OH}$ reactivity have previously only been observed downwind of or within urban sites such as the Mexico Metropolitan Area (median: $33 \mathrm{~s}^{-1}$; (Shirley et al., 2006), New York City (average: $19 \mathrm{~s}^{-1}$ (Ren et al., 2003) and Tokyo city (Average $30 \mathrm{~s}^{-1}$; (Sadanaga et al., 2005). In Section 3.2, we examine the strong wind sector dependence in the diurnal profile of some of the other measured chemical species as well be- fore discussing the implications of this on ozone chemistry in Sect. 3.3.

\subsection{Diurnal profile of radical species, formaldehyde and sulphur dioxide}

Figure 4 shows the measured average diurnal profiles of the $\mathrm{OH}$ radical, $\mathrm{HO}_{2}$ radical, $\mathrm{RO}_{2}^{*}$ radical, $\mathrm{HCHO}$ and $\mathrm{SO}_{2}$ for all the three wind sectors. It can be seen that for all the species shown in Fig. 4 with the exception of $\mathrm{SO}_{2}$, the trend of measured values follows the same as that observed for the measured $\mathrm{OH}$ reactivity, namely, continental sector values $>$ Huelva sector values $>$ ocean sector values. In particular, note that $\mathrm{HO}_{2}, \mathrm{RO}_{2}^{*}$ and $\mathrm{HCHO}$ are typically twice as high in air masses with strong continental influence compared to air masses from the Huelva and ocean sector, for most hours of the day. The $\mathrm{RO}_{2}^{*}$ data at 10:00 UTC is not shown due to insufficient number of $\mathrm{RO}_{2}^{*}$ measurements at this hour from this sector $(n=17)$ only due to calibration checks of this particular instrument, whereas all other $\mathrm{RO}_{2}^{*}$ data have $n>40$. None of these species would contribute significantly in terms of absolute magnitude to the measured $\mathrm{OH}$ reactivity and most are not even transported due to their short lifetimes but rather produced in-situ. Yet they do suggest strongly and independently from the $\mathrm{OH}$ reactivity measurements, that the continental air masses were very different from the other air masses in terms of chemical composition and likely richer in oxygenated VOCs which can contribute significantly to the $\mathrm{OH}$ reactivity (Lewis et al., 2000). Also in Fig. 4, it should be noted that $\mathrm{SO}_{2}$ is present at several ppb in air masses from the Huelva and ocean sector, but is almost zero in continental sector air masses. Crowley et al. (2011) have discussed the influence of Spain's largest paper mill which is located in Huelva in terms of malodorous sulphur emissions at ppbV level. The $\mathrm{SO}_{2}$ profile shown in Fig. 4 suggests that the Huelva and ocean sector air masses are characterized by higher $\mathrm{SO}_{2}$ due to strong sources of sulphur (refineries, ship traffic, paper mill). The proximity of those strong sources to the measurement site, would favour more efficient transport of the primary emissions and lower photochemical processing in air masses.

Such different "chemical" loadings and reactivity from different wind sectors at El Arenosillo, has important implications for the ozone chemistry at the site, and in the next few sections we examine the impact of the different air masses on the instantaneous diurnal ozone production regime and rates using different methods that have been proposed in previous works.

\subsection{Derivation of instantaneous ozone production regimes in air masses}

We assess whether the ozone production regime was limited by $\mathrm{NO}_{\mathrm{x}}$ or VOCs or both, using a method based on the approach of Kirchner et al. (2001). A second method based 
on the traditional $\mathrm{VOC} / \mathrm{NO}_{\mathrm{x}}$ ratio method as given in Seinfeld and Pandis (2006) is also described below but could not be applied due to absence of comprehensive VOC measurements. In studies where comprehensive VOC speciation, $\mathrm{NO}_{\mathrm{x}}$ measurements and direct $\mathrm{OH}$ reactivity measurements are available the two methods can be compared for consistency.

Conventionally, $\mathrm{OH}$ reactivity due to VOCs would require measurements of all individual VOCs followed by summation of their individual $\mathrm{OH}$ reactivities, which is the product of the VOC concentration and its reaction rate coefficient with the $\mathrm{OH}$ radical. The tremendous advantage of the directly measured total $\mathrm{OH}$ reactivity of air masses is that the $\mathrm{OH}$ reactivity due to VOCs is easily obtained by subtracting the $\mathrm{OH}$ reactivity of $\mathrm{NO}_{\mathrm{x}}$ from the directly measured total $\mathrm{OH}$ reactivity.

The $\mathrm{NO}_{\mathrm{x}} \mathrm{OH}$ reactivity for the air masses analyzed during DOMINO was calculated using $\mathrm{NO}$ and $\mathrm{NO}_{2}$ concentrations (obtained by using respective temperatures and pressures for the measured mixing ratios) and their pseudo first order reaction rate constants with the $\mathrm{OH}$ radical (Atkinson et al., 2004) as given by Eq. (1). Thus,

$\mathrm{NO}_{\mathrm{x}} \mathrm{OH}$ Reactivity

$=k_{\mathrm{OH}}+\mathrm{NO}_{2}\left[\mathrm{NO}_{2}+k_{\mathrm{OH}+\mathrm{NO}}[\mathrm{NO}]\right]$

and

VOC OH Reactivity = Total OH Reactivity -

$\mathrm{NO}_{\mathrm{x}} \mathrm{OH}$ Reactivity

Carbon monoxide's (CO) contribution is included in the VOC OH reactivity term as calculated above. The above approach also assumes that $\mathrm{OH}$ reactants other than $\mathrm{CO}$, VOCs and $\mathrm{NO}_{\mathrm{x}}$, do not contribute significantly to the directly measured $\mathrm{OH}$ reactivity, which is a reasonable assumption since most other abundant inorganic species (e.g. $\mathrm{O}_{3}, \mathrm{H}_{2} \mathrm{O}_{2}$ ) react only slowly with $\mathrm{OH}$ and $\mathrm{SO}_{2}$ contribution to $\mathrm{OH}$ reactivity during DOMINO is negligible.

Method 1: This method is based on the approach of Kirchner et al. (2001) and is quite useful when both direct $\mathrm{OH}$ reactivity and $\mathrm{NO}_{\mathrm{x}}$ measurements are available as was the case during DOMINO. Details about the extensive validation of this approach are available in the original work by Kirchner et al (2001). Briefly, this method makes use of an indicator ratio namely $\Theta={ }^{\mathrm{VOC}} \Gamma_{\mathrm{OH}} /{ }^{\mathrm{NO}} \times \Gamma_{\mathrm{OH}}$ which describes the ratio of the lifetime of the $\mathrm{OH}$ radical against the losses by reacting with VOCs and $\mathrm{NO}_{\mathrm{x}}$, respectively. Since the reactivity is the inverse of the respective lifetime for the extremely short lived $\mathrm{OH}$ radical, $\Theta=\mathrm{NO}_{\mathrm{x}} \mathrm{OH}$ Reactivity/VOC OH Reactivity. Kirchner et al. (2001) tested the validity of this indicator extensively against other indicators such as the $\mathrm{O}_{3} / \mathrm{NO}_{\mathrm{z}}$ ratio and $\mathrm{H}_{2} \mathrm{O}_{2} / \mathrm{HNO}_{3}$ ratio and found it to be robust. In contrast to the other indicators, $\Theta$ is not based on long lived species and therefore permits finding the instantaneous ozone production regime of an air parcel. As per this indicator method, for $\Theta>0.2( \pm 0.1)$, the ozone production regime is VOC limited, whereas for indicator values below 0.01 the ozone production regime would be primarily $\mathrm{NO}_{\mathrm{x}}$ limited. The intermediate range of $0.01<\Theta<0.2$, indicates that the ozone production depends strongly on both $\mathrm{NO}_{\mathrm{x}}$ and VOC levels.

Method 2: This method employs the ratios of VOC to $\mathrm{NO}_{\mathrm{x}}$ present in an air mass (Seinfeld and Pandis, 2006) and is based on observed characteristics of the average VOC-OH reaction rate constant (assumed as $2 \times 10^{-13} \mathrm{~cm}^{3}$ molec $\mathrm{C}^{-1} \mathrm{~s}^{-1}$; Seinfeld and Pandis, 2006) in a typical urban atmosphere. Accordingly, a VOC to $\mathrm{NO}_{\mathrm{x}}$ ratio $>5.5$ is indicative of a $\mathrm{NO}_{\mathrm{x}}$ limited ozone production regime, whereas a VOC to $\mathrm{NO}_{\mathrm{x}}$ ratio $<5.5$ indicates a VOC limited ozone production regime. For the ratio to be valid, the VOC concentration must be expressed on a per carbon atom basis. Note that the term VOC as defined in both Method 1 and Method 2 does not exclude carbon monoxide and methane. As mentioned earlier, both carbon monoxide and methane and indeed most of the important $\mathrm{C} 2-\mathrm{C} 8$ VOCs were not measured during DOMINO. Hence we are unable to apply this method for the DOMINO data.

Figure 5 shows a summary of the results. The top panel of Fig. 5 shows the instantaneous diurnal ozone production regime for each of the three air mass sectors, namely, continental (black markers), Huelva (red markers), and ocean (blue markers) using Method 1. The two bottom panels show the measured $\mathrm{NO}_{\mathrm{x}}\left(\mathrm{NO}, \mathrm{NO}_{2}\right)$ mixing ratios. A noteworthy feature is that the indicator ratios by Method 1 seem to be consistent within the levels of $\mathrm{NO}_{\mathrm{x}}$ present in the different air masses. For example the ozone production regime in the continental sector air masses is always a $\mathrm{NO}_{\mathrm{x}}$ limited regime, and the $\mathrm{NO}_{\mathrm{x}}$ mixing ratios measured in these air masses were also the lowest. A characteristic of $\mathrm{NO}_{\mathrm{x}}$ limited regimes is that before the end of the day most of it reacts away and this is also reflected in the diurnal trends of $\mathrm{NO}_{\mathrm{x}}$ measured in air masses from the continental sector. From the data shown in Fig. 5, it appears that there are occasions when ozone production in the Huelva and ocean sector air masses falls under a VOC limited regime. Looking at the high ppbV level $\mathrm{NO}_{\mathrm{x}}$ during these hours for the Huelva and ocean sectors, this might not seem surprising. However it should also be noted that on several such occasions (e.g. from 10:00-14:00 UTC), the values of the indicator ratios for Huelva and ocean sector air masses are at the border of the $\mathrm{NO}_{\mathrm{x}}$ and VOC limited regimes, making the case for a clear delineation of regimes weak for such cases. Towards the end of the day, as $\mathrm{NO}_{\mathrm{x}}$ levels decrease and photooxidation products are formed, the $\mathrm{O}_{3}$ production regime tends to become $\mathrm{NO}_{\mathrm{x}}$ limited.

In Sect. 3.3 we calculate rates of the instantaneous ozone production potential in air masses from the three sectors using two different methods that have been used in the literature. The first method helps assess the ozone production potential rate if ozone production at the site is no longer $\mathrm{NO}_{\mathrm{x}}$ limited while the second method provides the in-situ $\mathrm{O}_{3}$ production potential rate in different air masses based on in-situ 
levels of $\mathrm{NO}_{\mathrm{x}}$ and radicals measured during the DOMINO campaign.

\subsection{Derivation of rates of instantaneous ozone production potential}

Before presenting the expressions used for calculating the rates of the instantaneous ozone production potential, it is helpful to recall the main steps in ozone production from hydrocarbons

A generic hydrocarbon $\mathrm{RH}$ reacts with the $\mathrm{OH}$ radical in the presence of oxygen to form an alkyl peroxy radical $\left(\mathrm{RO}_{2}\right)$.

$\mathrm{RH}+\mathrm{OH}+\mathrm{O}_{2} \rightarrow \mathrm{RO}_{2}+\mathrm{H}_{2} \mathrm{O}$

Next, the alkyl peroxy radical reacts with NO when present,

$\mathrm{RO}_{2}+\mathrm{NO} \rightarrow \mathrm{RO}+\mathrm{NO}_{2}$

to produce an alkoxy radical that reacts with $\mathrm{O}_{2}$,

$\mathrm{RO}+\mathrm{O}_{2} \rightarrow$ carbonylcompound $+\mathrm{HO}_{2}$

The $\mathrm{HO}_{2}$ radical formed can also react with $\mathrm{NO}$ as in Reaction (R2)

$\mathrm{HO}_{2}+\mathrm{NO} \rightarrow \mathrm{OH}+\mathrm{NO}_{2}$

The $\mathrm{NO}_{2}$ molecules photodissociate to form oxygen atoms (O) that combine with molecular oxygen $\left(\mathrm{O}_{2}\right)$ and form ozone $\left(\mathrm{O}_{3}\right)$ :

$2 \mathrm{NO}_{2}+\mathrm{h} v \rightarrow 2 \mathrm{NO}+2 \mathrm{O}$

$2 \mathrm{O}+2 \mathrm{O}_{2} \rightarrow 2 \mathrm{O}_{3}$

Reactions (R1) to (R6) can be summarized as:

$\mathrm{RH}+4 \mathrm{O}_{2}+\mathrm{h} v \rightarrow \mathrm{H}_{2} \mathrm{O}+2 \mathrm{O}_{3}+$ carbonylcompound

Based on typical reaction rate constants, generally steps 2 to 6 , as shown above are faster than step 1 , and thus the latter reaction of the hydrocarbon with the $\mathrm{OH}$ radical is the rate determining step in production of ozone, which actually occurs in two steps (shown below as Reactions (R1a) and (R1b)) of which the first Reaction (R1a) is the slower and hence rate limiting:

$\mathrm{RH}+\mathrm{OH} \rightarrow \mathrm{R}+\mathrm{H}_{2} \mathrm{O}$

$\mathrm{R}+\mathrm{O}_{2} \rightarrow \mathrm{RO}_{2}$

The number of $\mathrm{O}_{3}$ molecules formed during the oxidation of a given hydrocarbon depends on the number of $\mathrm{NO}$ to $\mathrm{NO}_{2}$ conversions that occur during its oxidation and assuming that all peroxy radicals react only with $\mathrm{NO}$ (a reasonable assumption under sufficient $\mathrm{NO}_{\mathrm{x}}$ levels) and not amongst themselves, as a first approximation the ozone production potential due to a generic hydrocarbon can be expressed as:

$\mathrm{O}_{3}$ production potential $=\mathrm{k}_{\mathrm{RH}+\mathrm{OH}}[\mathrm{RH}][\mathrm{OH}] \times n$ where $n$ is the number of $\mathrm{NO}$ to $\mathrm{NO}_{2}$ conversions that occur during the oxidation of RH. As shown in the above example where two $\mathrm{NO}$ to $\mathrm{NO}_{2}$ conversions took place, $n=2$ is a reasonable value and is frequently used in Eq. (5) for assessing the $\mathrm{O}_{3}$ production potential of a given hydrocarbon (Hewitt, 1999 ) and policy for control of VOCs that act as ozone precursors. Note that using $n=2$, from Eq. (5) the total ozone production potential for an air mass can then be expressed as:

$\mathrm{O}_{3}$ production potential $=(\mathrm{VOC} \mathrm{OH}$ reactivity of air mass $)$

$\times[\mathrm{OH}] \times 2$

Where the VOC OH reactivity of air mass $=\sum k_{\mathrm{RH}+\mathrm{OH}}[\mathrm{RH}]$ For DOMINO, the VOC OH Reactivity can be obtained from the directly measured $\mathrm{OH}$ reactivity as explained in Sect. 3.2. $\mathrm{OH}$ mixing ratios were also measured using laser induced fluorescence (Martinez et al., 2010). The second method of estimating the $\mathrm{O}_{3}$ production potential in an air mass is based on the approach used previously by Sommariva et al. (2011) that uses measured mixing ratios of $\mathrm{RO}_{2}, \mathrm{HO}_{2}$ and $\mathrm{NO}$ and is given by:

$\mathrm{O}_{3}$ production potential $=\mathrm{k}_{\mathrm{HO}_{2}+\mathrm{NO}}\left[\mathrm{HO}_{2}\right][\mathrm{NO}]$

$+\sum \mathrm{k}_{\mathrm{RO}_{2} \mathrm{i}+\mathrm{NO}}\left[\mathrm{RO}_{2 \mathrm{i}}\right][\mathrm{NO}]$

In order to apply Eq. (7) for analysis of the DOMINO data, $\sum \mathrm{RO}_{2 i}$ was obtained by subtracting the measured $\mathrm{HO}_{2}$ from the measured $\mathrm{RO}_{2}^{*}$ and the reaction rate constants were taken from Atkinson et al. (2004). The value used for $k_{\mathrm{RO}_{2}+\mathrm{NO}}$ was $1 \times 10^{-11} \mathrm{~cm}^{3}$ molecule ${ }^{-1} \mathrm{~s}^{-1}$. Note that both methods of estimating the total ozone production potential of air masses give complementary information. The VOC $\mathrm{OH}$ reactivity based ozone production approach gives an estimate of the total ozone production potential of a given air mass and not necessarily the in-situ gross local ozone production, unless the entire VOC oxidation process takes place at the same site (which is seldom the case). Also the expression is valid only for air masses where $\mathrm{NO}_{\mathrm{x}}$ is not the limiting reactant. Nonetheless it is a very useful expression for a priori $\mathrm{O}_{3}$ production control and VOC emission control and hence used widely in urban atmospheres where $\mathrm{NO}_{\mathrm{x}}$ levels are usually high. The second approach which is based on in-situ measurements of $\mathrm{RO}_{2}, \mathrm{HO}_{2}$ and $\mathrm{NO}$ yields the gross local insitu $\mathrm{O}_{3}$ production but again as an upper limit since it also assumes that all the peroxy radicals react only with NO to form $\mathrm{NO}_{2}$ and all the $\mathrm{NO}_{2}$ formed thereby, photodissociates and forms $\mathrm{O}_{3}$ with $\mathrm{O}_{2}$. In reality $\mathrm{NO}_{2}$ can also react with $\mathrm{OH}$ forming $\mathrm{HNO}_{3}$, which reduces the $\mathrm{O}_{3}$ formation rate in high $\mathrm{NO}_{\mathrm{x}}$ environments by removing radicals from the system. As mentioned earlier, for the current analysis where the focus is on relative differences of the air masses sampled at the site and their impact on rates of the ozone formation potential, important inferences can be drawn by applying both methods to the measured data. Figure 6 shows the diurnal profile of $\mathrm{O}_{3}$ and the instantaneous rates of $\mathrm{O}_{3}$ production potential (black: continental sector; red: Huelva sector; blue: 


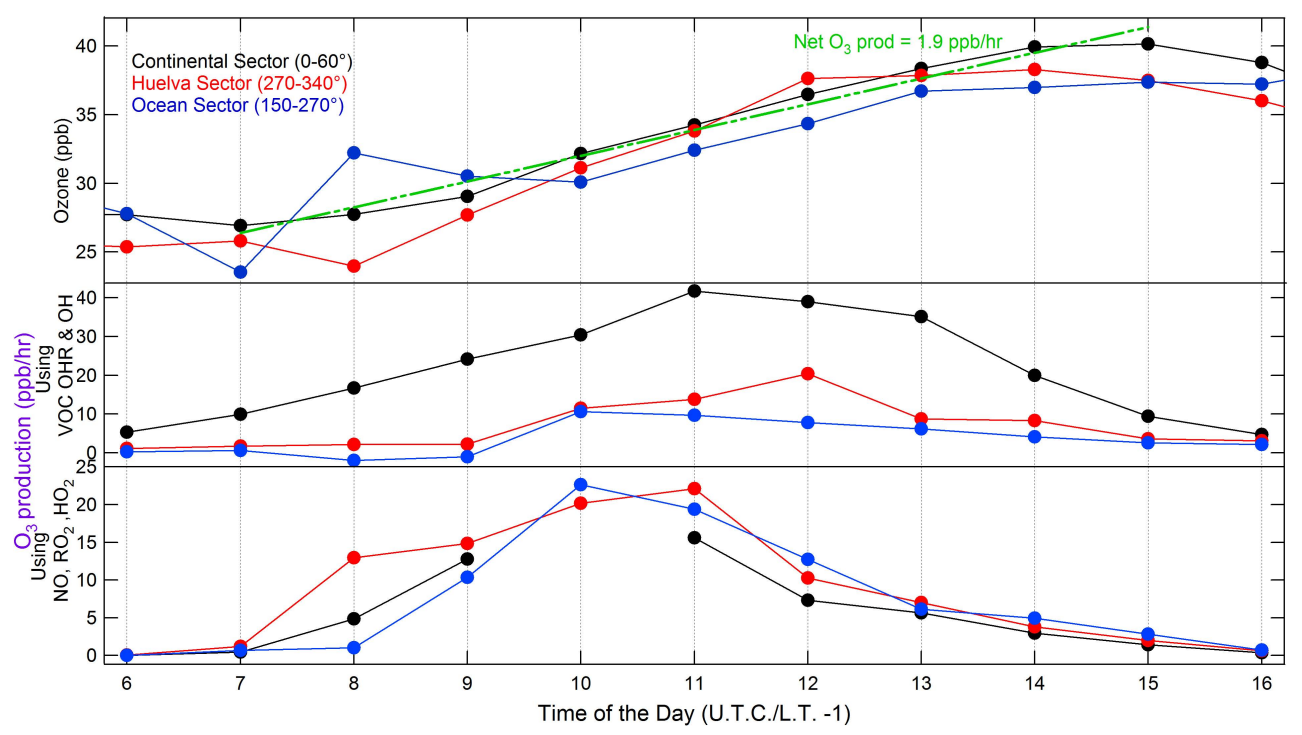

Fig. 6. Diurnal profile of $\mathrm{O}_{3}$ and the instantaneous rates of $\mathrm{O}_{3}$ production potential (black: continental sector; red: huelva sector; blue: ocean sector) derived from the in-situ measurements made at Base de Arenosillo, $37^{\circ} 05^{\prime} 58^{\prime \prime} \mathrm{N}, 6^{\circ} 44^{\prime} 17^{\prime \prime} \mathrm{W}$.

ocean sector) derived from the in-situ measurements at El Arenosillo. The average $\mathrm{O}_{3}$ mixing ratios between 07:00 and 16:00 UTC for each of the sectors differs by less than $2 \mathrm{ppb}$, with the peak values of $\sim 40 \mathrm{ppbV}$ occurring at 15:00 UTC in air masses from the continental sector. A linear fit (green dotted line in top panel of Fig. 6) to the measured $\mathrm{O}_{3}$ mixing ratios in air masses from the continental sector yields the slope for a net ozone production of $1.9 \mathrm{ppb} \mathrm{h}^{-1}$.

In stark contrast to similar values for the mixing ratios of ozone in air masses from the different sectors, the $\mathrm{O}_{3}$ production potential derived using the measured $\mathrm{VOC}-\mathrm{OH}$ reactivity and $\mathrm{OH}$ values (middle panel of Fig. 6) shows the highest rates of $\mathrm{O}_{3}$ production potential for the continental sector air masses with peak values of about $40 \mathrm{ppb} \mathrm{h}^{-1}$ at 11:00 UTC., which are incredibly high considering the actual measured levels of $\mathrm{O}_{3}$ at the site. The peak values in the Huelva and ocean sector air masses are less than $20 \mathrm{ppb} \mathrm{h}^{-1}$ using the same method. It should be noted here that high $\mathrm{O}_{3}$ production potential rates do not necessarily result in high $\mathrm{O}_{3}$ levels of the same proportion (e.g. in this case by factor of 2), since $\mathrm{O}_{3}$ concentrations are determined by the balance between its production and loss terms, and a large loss rate by several processes (e.g. photolysis, $\mathrm{NO}_{x}$ chemistry, ozonolysis reactions, and deposition) could still result in a smaller net $\mathrm{O}_{3}$ production rate. Rates of ozone production potential for the different air masses derived using in-situ measurements of $\mathrm{NO}, \mathrm{HO}_{2}$ and $\mathrm{RO}_{2}$ are shown in the bottom panel of Fig. 6. These show a completely different trend with higher rates of ozone production potential for the Huelva and ocean sectors compared to the continental sector which is the lowest. Remarkably, values of the ozone production potential using both methods are quite comparable for the Huelva and ocean sector air masses $\left(0-20 \mathrm{ppbh}^{-1}\right)$. Note also that from 13:00 UTC onwards both methods shows a steady decrease in the instantaneous $\mathrm{O}_{3}$ production rates in all air masses and converge to almost zero rates of $\mathrm{O}_{3}$ production at 16:00 UTC. It is worth mentioning that the values for instantaneous rates of $\mathrm{O}_{3}$ production observed are much lower than the $0-160 \mathrm{ppb} \mathrm{h}^{-1}$ range reported by Sommariva et al. (2011) during the TexAQS 2006 study. The main reason for this is that $\mathrm{NO}_{\mathrm{x}}$ levels, in particular for $\mathrm{NO}$ were significantly lower during DOMINO (average range: $\sim 0.1-5 \mathrm{ppbV}$ ) compared to the TexAQS study (average range: $\sim 0.7-15 \mathrm{ppbV}$ ).

The apparently irreconcilable trends in the rates of ozone production potential for different air masses using the two methods can be understood by noting from Sect. 3.2, that the ozone production regime at the site was mostly $\mathrm{NO}_{\mathrm{x}}$ limited, with air masses from the continental sector always falling in the $\mathrm{NO}_{\mathrm{x}}$ limited regime (Fig. 5). As mentioned earlier during the description of the methods, the estimation method based on VOC-OH reactivity, would be expected to perform accurately (though still an upper limit) only when $\mathrm{NO}_{\mathrm{x}}$ is not the limiting factor for $\mathrm{O}_{3}$ production. In contrast the method based on measured $\mathrm{HO}_{2}, \mathrm{RO}_{2}$ and $\mathrm{NO}$ performs better in explaining the observed ozone production at the site because it represents the local in-situ $\mathrm{O}_{3}$ production and includes the measured $\mathrm{NO}$ values in its formulation.

The combination of both methods however gives both the local and likely regional picture, for example in response to future $\mathrm{NO}_{\mathrm{x}}$ increases. The high rates of $\mathrm{O}_{3}$ production potential estimated by the VOC-OH reactivity based method, show that if strong sources of $\mathrm{NO}_{\mathrm{x}}$ come up in the future in the continental wind sector close to the site, $\mathrm{O}_{3}$ production rates at the site could increase by a factor of 2 .

This also implies that places located in the continental wind sector that are currently upwind of El Arenosillo could 
potentially be subject to similar impacts in terms of high rates of $\mathrm{O}_{3}$ production due to the addition of strong $\mathrm{NO}_{\mathrm{x}}$ sources.

\section{Conclusion}

The first dataset of direct $\mathrm{OH}$ reactivity measurements in ambient air from Spain at the coastal site El Arenosillo highlights the importance of direct $\mathrm{OH}$ reactivity measurements for classifying air masses based on their pollutant loading and constraining the in-situ instantaneous ozone production regimes and rates in combination with measurements of five parameters namely nitrogen oxides $\left(\mathrm{NO}, \mathrm{NO}_{2}\right), \mathrm{OH}$ and the peroxy radicals $\left(\mathrm{HO}_{2}\right.$ and $\left.\mathrm{RO}_{2}\right)$.

Although measurements of several important classes of VOCs (e.g. anthropogenic alkenes) were unavailable during DOMINO, direct $\mathrm{OH}$ reactivity measurements enabled classification of different air masses based on their reactive pollutant loading. Surprisingly, continental air masses from the north easterly direction with photochemically processed emissions from cities like Madrid and the Seville area were found to have significantly higher reactivity compared to the relatively "fresh" industrial emissions from Huelva which was north west of the measurement site at El Arenosillo. In stark contrast, clean marine air masses arriving at the site from the Atlantic ocean often had $\mathrm{OH}$ reactivity values which were below the instrument's detection limit $(<$ $\left.3.5 \mathrm{~s}^{-1}\right)$. Thus, extremely high variability was observed at this single site with values ranging from below detection limit to $85 \mathrm{~s}^{-1}$, covering the average range of $\mathrm{OH}$ reactivity values that have been reported in the literature from more than three quarters of all sites where such measurements have been performed (e.g. Table 1 of Lou et al., 2010.)

Using the method proposed by Kirchner et al. (2001), we show that using measurements of three parameters namely $\mathrm{NO}, \mathrm{NO}_{2}$ and $\mathrm{OH}$ reactivity, one can determine the instantaneous ozone production regime in different air masses at a single site which may be very helpful for policy decisions regarding ozone reduction and emissions control at specific locations. Further by calculating instantaneous ozone production rates using two different methods, we demonstrate the complementary information provided by both. However note that due to interferences on both the $\mathrm{OH}$ and $\mathrm{HO}_{2}$ measurements which caused the $\mathrm{HO}_{\mathrm{x}}$ measurements to be higher than the actual ambient levels, the values obtained in this study for the $\mathrm{O}_{3}$ production rates using both methods should also be regarded as upper limits.

In this particular study we found that the potential $\mathrm{O}_{3}$ production rates based on just the measured $\mathrm{VOC} \mathrm{OH}$ reactivity and $\mathrm{OH}$ radicals at El Arenosillo are very high when air masses arrive from the continental sector. The other approach of calculating the in-situ ozone production rates which takes into account NO and peroxy radical levels yields lower values as the site is predominantly a $\mathrm{NO}_{\mathrm{x}}$ limited regime.
The complementary information (one local and the other more regional) provided by employing both methods indicates that if upwind point sources of $\mathrm{NO}_{\mathrm{x}}$ were to increase north east of El Arenosillo with VOC emission levels staying the same as observed in this study, then gross ozone production rates at the site could potentially increase by a factor of two to $40 \mathrm{ppbVh}^{-1}$ leading to conditions favouring higher $\mathrm{O}_{3}$ levels, if the loss rates of $\mathrm{O}_{3}$ do not increase proportionally. On the other hand, based on the derived ozone production rates, it appears that addition of upwind point $\mathrm{NO}_{\mathrm{x}}$ sources north west of El Arenosillo may be less likely to cause conditions favouring similar higher levels of $\mathrm{O}_{3}$. This is assuming that the loss rates of $\mathrm{O}_{3}$ in this sector do not decrease much compared to those characteristic of the present study.

Such information made possible by direct $\mathrm{OH}$ reactivity measurements would be very useful for environmental impact assessment and policy decisions on urban planning efforts focussed on ozone reduction. With increasing urbanization and industrialization in the future, adding the $\mathrm{OH}$ reactivity measurements to pollution monitoring networks that already measure criteria air pollutants like $\mathrm{O}_{3}$ and $\mathrm{NO}_{x}$ would provide detailed in-situ $\mathrm{O}_{3}$ production regimes and rates.

Acknowledgements. We thank INTA (National Institute for Aerospace Technology) for providing facilities at the measurement site. NOAA Air Resources Laboratory (ARL) is gratefully acknowledged for the provision of the HYSPLIT transport and dispersion model (http://www.arl.noaa.gov/ready.html) used in this paper. All the participants of the DOMINO campaign are thanked for logistical support, in particular Thomas Custer.

The service charges for this open access publication have been covered by the Max Planck Society.

Edited by: M. Kanakidou

\section{References}

Adame, J. A., Lozano, A., Bolivar, J. P., De la Morena, B. A., Contreras, J., and Godoy, F.: Behavior, distribution and variability of surface ozone at an arid region in the south of Iberian Peninsula (Seville, Spain), Chemosphere, 70, 841-849, 2008.

Adame, J. A., Bolivar, J. P., and de la Morena, B. A.: Surface ozone measurements in the southwest of the Iberian Peninsula (Huelva, Spain), Environ. Sci. Pollut. R., 17, 355-368, 2010a.

Adame, J. A., Serrano, E., Bolivar, J. P., and de la Morena, B. A.: On the Tropospheric Ozone Variations in a Coastal Area of Southwestern Europe under a Mesoscale Circulation, J. Appl. Meteorol. Clim., 49, 748-759, 2010b.

Alastuey, A., Querol, X., Plana, F., Viana, M., Ruiz, C. R., de la Campa, A. S., de la Rosa, J., Mantilla, E., and dos Santos, S. G.: Identification and chemical characterization of industrial particulate matter sources in southwest Spain, J. Air Waste Manage., 56, 993-1006, 2006. 
Ammann, C., Brunner, A., Spirig, C., and Neftel, A.: Technical note: Water vapour concentration and flux measurements with PTR-MS, Atmos. Chem. Phys., 6, 4643-4651, doi:10.5194/acp6-4643-2006, 2006.

Atkinson, R., Aschmann, S. M., Winer, A. M., and Carter, W. P. L.: Rate Constants for the Gas-Phase Reactions of $\mathrm{OH}$ Radicals and $\mathrm{O}_{3}$ with Pyrrole at 295+/-1k and Atmospheric-Pressure, Atmos. Environ., 18, 2105-2107, 1984.

Atkinson, R.: Kinetics of the gas-phase reactions of $\mathrm{OH}$ radicals with alkanes and cycloalkanes, Atmos. Chem. Phys., 3, 22332307, doi:10.5194/acp-3-2233-2003, 2003.

Atkinson, R., Baulch, D. L., Cox, R. A., Crowley, J. N., Hampson, R. F., Hynes, R. G., Jenkin, M. E., Rossi, M. J., and Troe, J.: Evaluated kinetic and photochemical data for atmospheric chemistry: Volume $\mathrm{I}$ - gas phase reactions of $\mathrm{O}_{\mathrm{x}}, \mathrm{HO}_{\mathrm{x}}, \mathrm{NO}_{\mathrm{x}}$ and $\mathrm{SO}_{\mathrm{x}}$ species, Atmos. Chem. Phys., 4, 1461-1738, doi:10.5194/acp-41461-2004, 2004.

Butler, T. M., Lawrence, M. G., Taraborrelli, D., and Lelieveld, J.: Multi-day ozone production potential of volatile organic compounds calculated with a tagging approach, Atmos. Environ., 45, 4082-4090, doi:10.1016/j.atmosenv.2011.03.040, 2011.

Cantrell, C. A., Shetter, R. E., Lind, J. A., McDaniel, A. H., Calvert, J. G., Parrish, D. D., Fehsenfeld, F. C., Buhr, M. P., and Trainer, M.: An Improved Chemical Amplifier Technique for Peroxy Radical Measurements, J. Geophys. Res., 98, 2897-2909, doi:10.1029/92JD02842, 1993.

Crowley, J. N., Thieser, J., Tang, M. J., Schuster, G., Bozem, H., Beygi, Z. H., Fischer, H., Diesch, J.-M., Drewnick, F., Borrmann, S., Song, W., Yassaa, N., Williams, J., Pöhler, D., Platt, U., and Lelieveld, J.: Variable lifetimes and loss mechanisms for $\mathrm{NO}_{3}$ and $\mathrm{N}_{2} \mathrm{O}_{5}$ during the DOMINO campaign: contrasts between marine, urban and continental air, Atmos. Chem. Phys., 11, 10853-10870, doi:10.5194/acp-11-10853-2011, 2011.

Di Carlo, P., Brune, W. H., Martinez, M., Harder, H., Lesher, R., Ren, X. R., Thornberry, T., Carroll, M. A., Young, V., Shepson, P. B., Riemer, D., Apel, E., and Campbell, C.: Missing OH reactivity in a forest: Evidence for unknown reactive biogenic VOCs, Science, 304, 722-725, 2004.

Diesch, J.-M., Drewnick, F., Zorn, S. R., von der WeidenReinmüller, S.-L., Martinez, M., and Borrmann, S.: Variability of aerosol, gaseous pollutants and meteorological characteristics associated with changes in air mass origin at the SW Atlantic coast of Iberia, Atmos. Chem. Phys., 12, 3761-3782, doi:10.5194/acp12-3761-2012, 2012.

Draxler, R. R. and Rolph, G. D.: HYSPLIT (HYbrid Single-Particle Lagrangian Integrated Trajectory), Model access via NOAA ARL READY Website http://ready.arl.noaa.gov/HYSPLIT.php, NOAA Air Resources Laboratory, Silver Spring, MD, USA, 2011.

Fuchs, H., Bohn, B., Hofzumahaus, A., Holland, F., Lu, K. D., Nehr, S., Rohrer, F., and Wahner, A.: Detection of $\mathrm{HO}_{2}$ by laserinduced fluorescence: calibration and interferences from $\mathrm{RO} 2$ radicals, Atmos. Meas. Tech., 4, 1209-1225, doi:10.5194/amt4-1209-2011, 2011.

Hastie, D. R., Weißenmayer, M., Burrows, J. P., and Harris, G. W.: Calibrated chemical amplifier for atmospheric $\mathrm{RO}_{\mathrm{x}}$ measurements, Anal. Chem., 63, 2048-2057, 1991.

Hosaynali Beygi, Z., Fischer, H., Harder, H. D., Martinez, M., Sander, R., Williams, J., Brookes, D. M., Monks, P. S., and
Lelieveld, J.: Oxidation photochemistry in the Southern Atlantic boundary layer: unexpected deviations of photochemical steady state, Atmos. Chem. Phys., 11, 8497-8513, doi:10.5194/acp-118497-2011, 2011.

Ingham, T., Goddard, A., Whalley, L. K., Furneaux, K. L., Edwards, P. M., Seal, C. P., Self, D. E., Johnson, G. P., Read, K. A., Lee, J. D., and Heard, D. E.: A flow-tube based laser-induced fluorescence instrument to measure $\mathrm{OH}$ reactivity in the troposphere, Atmos. Meas. Tech., 2, 465-477, doi:10.5194/amt-2-465-2009, 2009.

Kartal, D., Andrés-Hernández, M. D., Reichert, L., Schlager, H., and Burrows, J. P.: Technical Note: Characterisation of a DUALER instrument for the airborne measurement of peroxy radicals during AMMA 2006, Atmos. Chem. Phys., 10, 30473062, doi:10.5194/acp-10-3047-2010, 2010.

Keenan, T., Niinemets, Ü., Sabate, S., Gracia, C., and Peñuelas, J.: Seasonality of monoterpene emission potentials in Quercus ilex and Pinus pinea: Implications for regional VOC emissions modeling, J. Geophys. Res., 114, D22202, doi:10.1029/2009JD011904, 2009.

Kirchner, F., Jeanneret, F., Clappier, A., Kruger, B., van den Bergh, H., and Calpini, B.: Total VOC reactivity in the planetary boundary layer 2. A new indicator for determining the sensitivity of the ozone production to VOC and $\mathrm{NO}_{\mathrm{x}}, \mathrm{J}$. Geophys. Res.-Atmos., 106, 3095-3110, doi:10.1029/2000jd900603, 2001.

Kovacs, T. A. and Brune, W. H.: Total OH loss rate measurement, J. Atmos. Chem., 39, 105-122, 2001.

Kovacs, T. A., Brune, W. H., Harder, H., Martinez, M., Simpas, J. B., Frost, G. J., Williams, E., Jobson, T., Stroud, C., Young, V., Fried, A., and Wert, B.: Direct measurements of urban $\mathrm{OH}$ reactivity during Nashville SOS in summer 1999, J. Environ. Monit., 5, 68-74, 2003.

Lee, J. D., Young, J. C., Read, K. A., Hamilton, J. F., Hopkins, J. R., Lewis, A. C., Bandy, B. J., Davey, J., Edwards, P., Ingham, T., Self, D. E., Smith, S. C., Pilling, M. J., and Heard, D. E.: Measurement and calculation of $\mathrm{OH}$ reactivity at a United Kingdom coastal site, J. Atmos. Chem., 64, 53-76, doi:10.1007/s10874010-9171-0, 2009.

Lelieveld, J., Dentener, F. J., Peters, W., and Krol, M. C.: On the role of hydroxyl radicals in the self-cleansing capacity of the troposphere, Atmos. Chem. Phys., 4, 2337-2344, doi:10.5194/acp4-2337-2004, 2004.

Lewis, A. C., Carslaw, N., Marriott, P. J., Kinghorn, R. M., Morrison, P., Lee, A. L., Bartle, K. D., and Pilling, M. J.: A larger pool of ozone-forming carbon compounds in urban atmospheres, Nature, 405, 778-781, 2000.

Lou, S., Holland, F., Rohrer, F., Lu, K., Bohn, B., Brauers, T., Chang, C.C., Fuchs, H., Häseler, R., Kita, K., Kondo, Y., Li, X., Shao, M., Zeng, L., Wahner, A., Zhang, Y., Wang, W., and Hofzumahaus, A.: Atmospheric $\mathrm{OH}$ reactivities in the Pearl River Delta - China in summer 2006: measurement and model results, Atmos. Chem. Phys., 10, 11243-11260, doi:10.5194/acp-10-11243-2010, 2010.

Mao, J., Ren, X., Brune, W. H., Olson, J. R., Crawford, J. H., Fried, A., Huey, L. G., Cohen, R. C., Heikes, B., Singh, H. B., Blake, D. R., Sachse, G. W., Diskin, G. S., Hall, S. R., and Shetter, R. E.: Airborne measurement of OH reactivity during INTEX-B, Atmos. Chem. Phys., 9, 163-173, doi:10.5194/acp-9-163-2009, 2009. 
Martinez, M., Harder, H., Kovacs, T. A., Simpas, J. B., Bassis, J., Lesher, R., Brune, W. H., Frost, G. J., Williams, E. J., Stroud, C. A., Jobson, B. T., Roberts, J. M., Hall, S. R., Shetter, R. E., Wert, B., Fried, A., Alicke, B., Stutz, J., Young, V. L., White, A. B., and Zamora, R. J.: $\mathrm{OH}$ and $\mathrm{HO}_{2}$ concentrations, sources, and loss rates during the Southern Oxidants Study in Nashville, Tennessee, summer 1999, J. Geophys. Res.-Atmos., 108, 4617, doi:10.1029/2003JD003551, 2003.

Martinez, M., Harder, H., Kubistin, D., Rudolf, M., Bozem, H., Eerdekens, G., Fischer, H., Klüpfel, T., Gurk, C., Königstedt, R., Parchatka, U., Schiller, C. L., Stickler, A., Williams, J., and Lelieveld, J.: Hydroxyl radicals in the tropical troposphere over the Suriname rainforest: airborne measurements, Atmos. Chem. Phys., 10, 3759-3773, doi:10.5194/acp-10-3759-2010, 2010.

Monks, P. S., Granier, C., Fuzzi, S., Stohl, A., Williams, M. L., Akimoto, H., Amann, M., Baklanov, A., Baltensperger, U., Bey, I., Blake, N., Blake, R. S., Carslaw, K., Cooper, O. R., Dentener, F., Fowler, D., Fragkou, E., Frost, G. J., Generoso, S., Ginoux, P., Grewe, V., Guenther, A., Hansson, H. C., Henne, S., Hjorth, J., Hofzumahaus, A., Huntrieser, H., Isaksen, I. S. A., Jenkin, M. E., Kaiser, J., Kanakidou, M., Klimont, Z., Kulmala, M., Laj, P., Lawrence, M. G., Lee, J. D., Liousse, C., Maione, M., McFiggans, G., Metzger, A., Mieville, A., Moussiopoulos, N., Orlando, J. J., O'Dowd, C. D., Palmer, P. I., Parrish, D. D., Petzold, A., Platt, U., Poschl, U., Prevot, A. S. H., Reeves, C. E., Reimann, S., Rudich, Y., Sellegri, K., Steinbrecher, R., Simpson, D., ten Brink, H., Theloke, J., van der Werf, G. R., Vautard, R., Vestreng, V., Vlachokostas, C., and von Glasow, R.: Atmospheric composition change - global and regional air quality, Atmos. Environ., 43, 5268-5350, 2009.

Ren, X. R., Harder, H., Martinez, M., Lesher, R. L., Oliger, A., Shirley, T., Adams, J., Simpas, J. B., and Brune, W. H.: $\mathrm{HO}_{\mathrm{x}}$ concentrations and $\mathrm{OH}$ reactivity observations in New York City during PMTACS-NY2001, Atmos. Environ., 37, 3627-3637, 2003.

Ren, X. R., Brune, W. H., Oliger, A., Metcalf, A. R., Simpas, J. B., Shirley, T., Schwab, J. J., Bai, C. H., Roychowdhury, U., Li, Y. Q., Cai, C. X., Demerjian, K. L., He, Y., Zhou, X. L., Gao, H. L., and $\mathrm{Hou}, \mathrm{J} .: \mathrm{OH}, \mathrm{HO}_{2}$, and $\mathrm{OH}$ reactivity during the PMTACS-NY Whiteface Mountain 2002 campaign: Observations and model comparison, J. Geophys. Res.-Atmos., 111, D10S03, doi:10.1029/2005JD006126, 2006.

Sadanaga, Y., Yoshino, A., Kato, S., Yoshioka, A., Watanabe, K., Miyakawa, Y., Hayashi, I., Ichikawa, M., Matsumoto, J., Nishiyama, A., Akiyama, N., Kanaya, Y., and Kajii, Y.: The importance of $\mathrm{NO}_{2}$ and volatile organic compounds in the urban air from the viewpoint of the OH reactivity, Geophys. Res. Lett., 31, L08102, doi:10.1029/2004GL019661, 2004a.

Sadanaga, Y., Yoshino, A., Watanabe, K., Yoshioka, A., Wakazono, Y., Kanaya, Y., and Kajii, Y.: Development of a measurement system of $\mathrm{OH}$ reactivity in the atmosphere by using a laserinduced pump and probe technique, Rev. Sci. Instrum., 75, 26482655, 2004b.

Sadanaga, Y., Yoshino, A., Kato, S., and Kajii, Y.: Measurements of $\mathrm{OH}$ reactivity and photochemical ozone production in the urban atmosphere, Environ. Sci. Technol., 39, 8847-8852, 2005.
Seinfeld, J. H. and Pandis. S. N.: Chapter 6, Atmospheric Chemistry and Physics - From Air Pollution to Climate Change, Second Edition ed., John Wiley \& Sons, Inc, New Jersey, USA, 2006.

Shirley, T. R., Brune, W. H., Ren, X., Mao, J., Lesher, R., Cardenas, B., Volkamer, R., Molina, L. T., Molina, M. J., Lamb, B., Velasco, E., Jobson, T., and Alexander, M.: Atmospheric oxidation in the Mexico City Metropolitan Area (MCMA) during April 2003, Atmos. Chem. Phys., 6, 2753-2765, doi:10.5194/acp-62753-2006, 2006.

Sinha, V., Williams, J., Crutzen, P. J., and Lelieveld, J.: Methane emissions from boreal and tropical forest ecosystems derived from in-situ measurements, Atmos. Chem. Phys. Discuss., 7, 14011-14039, doi:10.5194/acpd-7-14011-2007, 2007.

Sinha, V., Williams, J., Crowley, J. N., and Lelieveld, J.: The Comparative Reactivity Method - a new tool to measure total $\mathrm{OH}$ Reactivity in ambient air, Atmos. Chem. Phys., 8, 2213-2227, doi:10.5194/acp-8-2213-2008, 2008.

Sinha, V., Custer, T. G., Kluepfel, T., and Williams, J.: The effect of relative humidity on the detection of pyrrole by PTR-MS for $\mathrm{OH}$ reactivity measurements, Int. J. Mass Spectrom., 282, 108-111, 2009.

Sinha, V., Williams, J., Lelieveld, J., Ruuskanen, T. M., Kajos, M. K., Patokoski, J., Hellen, H., Hakola, H., Mogensen, D., Boy, M., Rinne, J., and Kulmala, M.: OH Reactivity Measurements within a Boreal Forest: Evidence for Unknown Reactive Emissions, Environ. Sci. Technol., 44, 6614-6620, 2010.

Sommariva, R., Brown, S. S., Roberts, J. M., Brookes, D. M., Parker, A. E., Monks, P. S., Bates, T. S., Bon, D., de Gouw, J. A., Frost, G. J., Gilman, J. B., Goldan, P. D., Herndon, S. C., Kuster, W. C., Lerner, B. M., Osthoff, H. D., Tucker, S. C., Warneke, C., Williams, E. J., and Zahniser, M. S.: Ozone production in remote oceanic and industrial areas derived from ship based measurements of peroxy radicals during TexAQS 2006, Atmos. Chem. Phys., 11, 2471-2485, doi:10.5194/acp-11-2471-2011, 2011.

Song, W. Williams, J., Yassaa, N., Martinez, M., Carnero, J. A. A., Hidalgo, P. J., Bozem, H., Lelieveld, J.: Winter and summer characterization of biogenic enantiomeric monoterpenes and anthropogenic BTEX compounds at a Mediterranean Stone Pine forest site, J. Atmos. Chem., 68, 233-250, doi:10.1007/s10874012-9219-4, 2011.

Sörgel, M., Regelin, E., Bozem, H., Diesch, J. M., Drewnick, F., Fischer, H., Harder, H., Held, A., Hosaynali-Beygi, Z., Martinez, M., and Zetzsch, C.: Quantification of the unknown HONO daytime source and its relation to $\mathrm{NO}_{2}$, Atmos. Chem. Phys., 11, 10433-10447, doi:10.5194/acp-11-10433-2011, 2011.

Staudt, M., Bertin, N., Frenzel, B., and Seufert, G.: Seasonal variation in amount and composition of monoterpenes emitted by young Pinus pinea trees - Implications for emission modeling, J. Atmos. Chem., 35, 77-99, doi:10.1023/a:1006233010748, 2000.

Yoshino, A., Sadanaga, Y., Watanabe, K., Kato, S., Miyakawa, Y., Matsumoto, J., and Kajii, Y.: Measurement of total OH reactivity by laser-induced pump and probe technique - comprehensive observations in the urban atmosphere of Tokyo, Atmos. Environ., 40, 7869-7881, 2006. 